\title{
Tumor Cell Dormancy: Threat or Opportunity in the Fight Against Cancer
}

\author{
Khaled Seidi ${ }^{1}$, Masoud H. Manjili ${ }^{2}$, Rana Jahanban-Esfahlan ${ }^{1,3^{*}}$, Tahereh Javaheri ${ }^{4,5^{*}}$ \\ ${ }^{1}$ Department of Medical Biotechnology, Faculty of Advanced Medical Sciences, Tabriz University of Medical Sciences, Tabriz, \\ Iran.Email: Kh.seidi@yahoo.com \\ ${ }^{2}$ Department of Microbiology \& Immunology, VCU School of Medicine, Massey Cancer Center, Richmond, Virginia. Email: \\ masoud.manjili@vcuhealth.org.
}

${ }^{3}$ Student research committee, Tabriz University of Medical Sciences, Tabriz, Iran. Email: rana.jahanban@gmail.com.

${ }^{4}$ Ludwig Boltzmann Institute for Cancer Research, 1090 Vienna, Austria.

${ }^{5}$ Institute of Animal Breeding and Genetics, University of Veterinary Medicine Vienna, 1210 Vienna, Austria. Email:

Tahereh.Javaheri@lbicr.lbg.ac.at.

\section{*Correspondence should be addressed to:}

Rana Jahanban-Esfahlan, Department of Medical Biotechnology, Faculty of Advanced Medical Sciences, Tabriz University of Medical Sciences, Tabriz, Iran. Daneshgah street, Postal code: 516661-4733, Tabriz, East Azerbaijan, Iran. Mobile: +98 930606 5370, Tel: +98 4133372072. Email: Jahanbanr@tbzmed.ac.ir.

Tahereh Javaheri, Ludwig Boltzmann Institute for Cancer Research, Institute of Animal Breeding and Genetics, University of Veterinary Medicine, Austria. Phone: (+43-1)- 25077 563, Fax: (+43-1)- 40160 931300. Email:

Tahereh.Javaheri@lbicr.lbg.ac.at.

Running title: Leveraging tumor cell dormancy to control cancer 


\begin{abstract}
Tumor dormancy, a clinically undetectable state of cancer, makes a major contribution to the development of multidrug resistance (MDR), minimum residual disease (MRD), tumor outgrowth, cancer relapse, and metastasis. Despite its high incidence, the whole picture of dormancy-regulated molecular programs is far from clear. That is, it is unknown when and which dormant cells will resume proliferation causing late relapse, and which will remain asymptomatic and harmless to their hosts. Thus, identification of dormancy-related culprits and understanding their roles can help predict cancer prognosis and may increase the probability of a timely therapeutic intervention for the desired outcome. Here, we provide a comprehensive review of the dormancy-dictated molecular mechanisms, including an angiogenic switch, immune escape, cancer stem cells, extra cellular matrix (ECM) remodeling, metabolic reprogramming, miRNAs, epigenetic modifications, and stress-induced-p38 signaling pathways. Further, we analyze the possibility of leveraging these dormancy-related molecular cues to outmaneuver cancer, and discuss the implications of such approaches in cancer treatment.
\end{abstract}

Key words: tumor dormancy; tumor relapse; tumor escape; metastasis; cancer therapy 


\section{Introduction}

Microorganisms adopt different mechanisms to survive under hostile conditions. They undergo drastic changes in cellular physiology to shape the surrounding microenvironment to best fit their requirements [1,2]. In response to a stressor such as chemotherapy, radiation therapy, or $\mathrm{O}_{2} /$ nutrient scarcity, stressed-tumor cells that survive apoptosis become dormant [3-6]. After cessation of the therapy, the dormant cells may repopulate, resulting in tumor recurrence and development of chemotherapy-resistant cancer cells $[7,8]$.

Dormant cells can be detected as circulating tumor cells (CTCs) in the bloodstream or disseminated cells (DTCs) in the bone marrow [9,10]. Once metastatic cells find a new home to settle, they may have different fates: they either die, may remain silent (restrictive soil), or seek vengeance and come back with an even more aggressive and lethal behavior than before (permissive soil) [11,12]. The implication of tumor cell dormancy is very well established in the development of multidrug resistance (MDR), minimum residual disease (MRD), tumor outgrowth, and metastatic relapse [13-15], leading to cancer treatment failure.

With regard to their nature, two type of dormant cancer cells can be recognized: dormant cells within the hypoxic middle layers of primary tumor which survive anti-proliferative treatments including chemotherapy, anti-angiogenesis, and tumor vascular disruption, in which a ring of viable tumor cells remain at the edge of tumor $[16,17]$ following therapy and derive tumor regrowth and drug resistance [18-22]. These dormant cells, namely rim cells are discussed in depth elsewhere [18]. The second type of dormant cells referred to as disseminated tumor cells (DTCs), is responsible for the emergence of lethal and metastatic outbreaks which are detected mostly within several years after therapy [23-25]. Given to their critical significance in patient survival, this article is focused on the roles of DTCs in cancer.

Since the complete cure of cancer is tied to the dormancy state of tumor cells, the question is whether we can leverage this threat into an opportunity to cure cancer for good. Is there any way around killing sleeping devil or putting it to sleep for a lifespan? Alternatively, can we avoid the emergence of dormant cells in the first place to put an end to the worries of tumor relapse? To answer these questions, we review the stealth mechanisms dictating tumor dormancy and then we analyze the possibility of leveraging dormancy related molecular cues to outmaneuver cancer. Finally, the implication of each approach to cancer treatment and prognosis is discussed.

\section{Learn dormancy tactics, use it against cancer, and rewrite cancer cell fate}

The equilibrium between tumor hibernation and tumor awaking is governed by several mechanisms including an angiogenic switch, immune escape, cancer stem cells, ECM remodeling, metabolic reprogramming, miRNAs, epigenetic modifications, and p38 signaling (Table. 1).

\section{Angiogenic switch}

One contributing factor to tumor dormancy is the incompetence of proliferating tumors to acquire the angiogenic potential to induce the formation of new blood vessels [26]. In the same way, the ability to drive tumor angiogenesis process will promote the escape from latency and initiate tumor outgrowth. This point of cancer progression is recognized as an angiogenic switch, the induction 
of which is under the control of intricate biological processes comprising the cancer cells, bone marrow-derived endothelial precursors, and tumor associated-stromal microenvironment [27].

Angiogenesis switch, or in a better word, angiogenic failure is a key piece of the dormancy puzzle. The role of angiogenic dormancy has been highlighted by the observations that anti-angiogenic therapies or angiogenic therapies could induce tumor dormancy or rescue dormant cells, respectively (Table. 1). As such, angiogenic factors display a reduced expression in dormant cells, meanwhile, the high transcription level of angiogenesis inhibitors such as Angiostatin, Endostatin, and Thrombospondin-1 is associated with the tumor dormancy.

With regard to the role of the angiogenic switch in tumor dormancy, two therapeutic approaches follow: in the first approach, long-term dormancy can be induced using anti-angiogenic therapy [28]. For example, cancer patients may benefit from bioactive Angiostatin gene therapy; however, transgene delivery may necessitate repetitive drug administration to assure persistent latency state of primary tumors and control metastatic expansion, that is not clinically feasible because of offtarget effects and also efficiency [29]. Also, eradication of primary tumors which result in inducing dormant tumor cells is evidenced by the high expression level of angiogenic inhibitor Thrombospondin-1 in human melanoma xenografts (D-12, R-18, and U-25). In contrast to wildtype tumors with no Thrombospondin-1 expression, a tumor suppressive index was demonstrated only in mice bearing D-12, U-25, or Thrombospondin-1 overexpressing R-18 tumors, as validated by melanoma angiogenesis, lung colonization, and spontaneous pulmonary metastasis [30]. These results suggest a combination of sustained anti-angiogenic therapy besides local treatment for melanoma therapy. Impaired tumor angiogenesis also drives prolonged dormancy of human liposarcoma. This type of tumor with no angiogenic activity produce moderately high amount of the anti-angiogenesis agents TIMP-1 and Thrombospondin-1, proposing that the nonangiogenic, microscopic, dormant stage of melanoma might be susceptible to anti-angiogenic treatment years prior to manifestation of malignant disease, or macroscopically detection of anatomical site of a given tumor, by current approaches [31]. Notably, metastatic dormancy can be realized once proliferation of tumor cell is well-balanced with an equal ratio of tumor cell apoptosis, indicating that anti-angiogenic treatment regulates metastatic outgrowth through increasing of cancer cell death [32].

In addition, the dormancy process can be reversed when dormant cells are fed with adequate angiogenic factors. The reversibility of dormancy affords the second approach based on awakening the ugly sleepy by switching silent cells into proliferative and yet susceptible cancer cells to further anti-angiogenic therapy. Studies on engineered organotypic microvascular niches established that while a Thrombospondin- 1 secretion from endothelial cells induces maintained BCC dormancy, bioactive Periostin and TGF- $\beta 1$ function as tumor-promoting factors in sprouting neovasculature which further sparks micrometastatic outgrowth [33]. Moreover, the shift of resting tumors was shown to be correlated with the downregulation of Thrombospondin and a reduced response to Angiostatin in angiogenic tumors. The transformation of quiescent tumors to highly proliferating tumors was also associated with the activation and regulation of molecular cues connected to tumor dormancy [34]. Also, engineered WM1341B cells constitutively overexpressing the vascular endothelial growth factor (VEGF)/vascular permeability factor (VPF) isoform are shown to terminate long-term melanoma dormancy and can induce overt and progressively growing tumors. These effects were largely counteracted by neutralizing VEGF activity in mice [35]. 


\section{Immunoediting/ immune escape}

The tumor-host interactions are progressively known as crucial constituents of cancer growth or inhibition. Particularly, infiltrating immune cells are critical features of tumor microenvironment [36]. Cancer cells are encircled by stromal cells, including macrophages, fibroblasts, mast cells, neutrophils, and lymphocytes, which communicate through an intricate system of intercellular signaling pathways, mediated by cytokines, adhesion molecules, and the receptor-ligand network [37]. The immune system can confine the metastatic spread of cancer cells, encouraging their longlasting latency. Nonetheless, the perturbation of the equilibration in favor of immune escape tumor clones will result in tumor outgrowth rather than the destruction of cancer cells, otherwise, immune surveillance could maintain angiogenic control and impede cancer cell growth [38] (Fig. 1). To this end, CD8+ T cells play a key role in maintaining tumor dormancy, and the expression of MHC class I on the surface of tumor cells also play a role in this critical equilibrium. Natural killer (NK) cells act as activators that prompt a cytotoxic T lymphocyte (CTL) response [39], meanwhile, an association of human Tregs, neutrophils and inflammatory mediators such as interferon gamma (IFN $\gamma$ ) are rather context-dependent [40]. Immunotherapeutics that target disseminated cancer dormancy may aid to control or eliminate cancer state. In this view, treatment modalities that induce or amplify the CTL immune response or abrogate CTL immunosuppression mediated by cancer cells might be beneficial to confine or eradicate metastatic cells $[41,42]$.

Dormancy state induced by the elimination of primary tumor can be avoided by a 'recombinant $\mathrm{T}$ cell receptor ligand therapy', dosing days in advance to tumor resection and lasting throughout the whole treatment course, that is a highly speculative therapy [43]. Alternatively, immune-stimulated dormancy pathway can be tuned to reverse dormancy and favor dormant cell eradication. For instance, blocking IDO-kynurenine-AhR metabolic circuitry abolishes immunologic latency mediated by IFN- $\gamma$ in tumor-repopulating cells (TRCs). Hypothetically, the IFN- $\gamma$-STAT1 signaling induces apoptosis in proliferating tumor cells; however, TRCs-induced overexpression of IDO1 and AhR, shifts IFN- $\gamma$ action and give rise to IDO1/AhR-induced p27 activation and inhibition of STAT1 signaling. Further, these events translate into the inhibition of tumor cell apoptosis and thus switching to dormancy program. Blockade of IDO/AhR metabolic circuitry not only nullifies IFN- $\gamma$-mediated latency but also promotes amplified tumor cell growth arrest by IFN- $\gamma$-dependent killing of TRCs in vitro and in vivo [44,45]. Dormant tumor cells may hinder CTL-mediated tumor lysis via overexpressing B7-H1 and B7.1 [37,46]. They also counteract apoptosis by paracrine secretion of cytokines (e.g. IL-3) and simultaneous inactivation of SOCS1, the expression of which negatively controls JAK/STAT signaling [47]. In this context, demethylation or gene transfer was shown to restore the expression of SOCS1, which further rendered dormant cells sensitive to apoptosis and abrogated resistance to CTL-induced tumor cell destruction. Moreover, the cross-resistance to apoptosis emanating from dormant tumor cellinduced overproduction of Interleukin 3 (IL-3) was upturned using anti-IL-3 antibody [47].

Alternatively, 'recombinant $\mathrm{T}$ cell receptor ligand therapy' of overt cancer may retain all undetectable DTCs quiescent providing that the treatment is continued as a plan to control cancer [43]. Thus, preventing metastatic expansion would be more feasible than eliminating an established metastasis [43]. As such, tumor-cell immunization prompts tumor cell latency in mice bearing Bcell aggressive leukemia/lymphoma (BCL1). In this line, while an anti-idiotypic immunity was insufficient to eliminate BCL1 cells, it was capable of suppressing growth activating signals, which further promoted cell cycle arrest, apoptosis and persistent BCL1 dormancy in mice[48]. Also, immunity to BCL1, which was achieved by numerous inoculations of irradiated carcinoma cells, 
precludes leukemia growth in primary and adoptive transfer recipients even with the lifelong perseverance of residual cancer cells [49].

Increasing inflammation promotes tumor recurrence, thus interventions that inhibit inflammatory signaling could inhibit tumor recurrence[50,51]. To this end, it was reported that inflammation and wound healing process following surgery is enough to induce distant cancer outgrowth[52], especially when the tumor outgrowth was attenuated by the adaptive immune system [53]. Accordingly, anti-inflammatory medications can benefit cancer patients undergoing surgery by avoiding the awakening of latent micrometastatic cells. Furthermore, it was shown that the lipopolysaccharide treatment-induced localized inflammation in the lungs, sends a wake-up signal to metastatic latency in the lung parenchyma through Zeb1 expression, a key regulator of the epithelial-to-mesenchymal transition (EMT). Likewise, Zeb1-orchestrated stimulation of EMT program by itself is sufficient to provoke metastatic spread by triggering stable entry of tumor cells into a state of metastasis-initiating cells [54]. Accordingly, inhibition of Zeb1, LIFR: STAT3 signaling [55] as well as blocking the actions of inflammatory cytokines such as tumor necrosis factor $\alpha(\mathrm{TNF} \alpha)$ and IL-1 $\beta$ cytokines could confer dormancy and thus eliminate cancer outgrowth [56].

\section{Metabolic reprogramming}

Impaired vascular system observed in solid tumors encourage establishing oxygen and nutrients deprived microenvironments that harbor metabolically stressed slow growing cells [20,21,57]. Tumor cells under hypoxia and nutrient deprivation become dormant by reducing or shifting their metabolic needs. A second deprivation assault would shut down the possible energy compensatory options for tumor cells and succumb them to apoptotic death. As such, small molecule VLX600 displays superior cytotoxic action in nutrient-starved environments and is preferentially active against quiescent cells. The anti-tumor potential is correlated with dampened mitochondrial respiration, culminating in bioenergetic catastrophe and tumor cell apoptosis [58]. Another study has shown the superior performance of FF-10502, a pyrimidine nucleoside antimetabolite over gemcitabine on pancreatic dormant cells, by inducing dormant cell injury in chemotherapy-resistant cells through blocking with DNA polymerase $\beta$ activity and DNA repair [59].

Likewise, in residual breast cancer, metabolic shifts promote tumor relapse. Blockade of either transportation of fatty acid into mitochondria or synthesis of cellular fatty acid lessens DNA damages and cellular reactive oxygen species (ROS) levels, connecting these hallmarks to lipid metabolism. Tumor relapse can be prevented by direct disruption of these features, either by mitigating expansion of the residual breast cell population or scavenging ROS [60].

Also, reinforcing a quiescence-like metabolic state can block tumor evasion. In this regard, a novel metabolic tumor suppressor, LACTB reduce PISD protein abundance and PE/LPE production, resulting in a mitochondrial state compatible consisted of reduced proliferation, increased epithelial phenotype, and a decrease in mesenchymal and cancer stem cell markers, which associate to tumor regression and inhibition of tumor formation. Conversely, LACTB silencing in non-tumorigenic breast cell lines cooperated with oncogenic drivers (HRASG12V and MYCT58A) supporting tumor formation in xenotransplants [61,62]. Notably, results from a recent study showed the role of autophagy as an important regulator of tumor cell dormancy. That, the 
lack of autophagy, which exploits as an important compensatory mechanism by tumor cells for providing energy, associated with an early breast cancer recurrence and escape from dormancy[63]

\section{Extracellular matrix (ECM) remodeling}

The likely involvement of communications between ECM and tumor cells in metastatic niches determine tumor latency against the metastatic outbreak. Generally, the inability of cancer cells to appropriately adhere the ECM may potentiate their entry into a dormancy state [64]. As shown in Fig. 2, inhibition of one of the components of Fibronectin/uPAR/Integrin/ERK/MLCK signaling axis as well as suppressing PI3K/Akt pathway is enough to prevent/treat metastatic tumor growth, meanwhile promoting dormancy state through favoring the p38 MAPK signaling $[65,66]$. In one study, the switch from dormancy to the proliferating state of D2A1 cells was reliant on the production of Fibronectin and $\beta 1$ Integrin signaling, the formation of filamentous actin (F-actin) stress fiber and cytoskeletal reorganization. Integrin $\beta 1$-dependant phosphorylation of myosin light chain (MLC) by MLC kinase (MLCK) was a prerequisite for F-actin stress fiber formation and exponentially growing of cancer cells. Blockade of $\beta 1$ integrin or MLCK favored dormancy state and MLCK inhibition significantly reduced metastatic expansion in vivo [67]. Similarly, deposition of type I collagen (Col-I) is shown to induce transition of dormant D2.0R cells to proliferating cells by $\beta 1$ Integrin-mediated Src and focal adhesion kinase (FAK) activation, causing extracellular signal-regulated kinase (ERK)-dependent phosphorylation of MLC by MLCK and formation of actin stress fiber. Blockade of $\beta 1$-integrin, MLCK, ERK, Src counteracted Col-Imediated induction of this signaling cascade, cytoskeletal rearrangement, and proliferating state [68]. Likewise, Src knockdown or pharmacological blocking of SFK signaling promote p27 localization to the nucleus and thwarts transition of quiescent breast cancer cells (BCCs) into the proliferative and metastatic outbreak; still, SFK inhibition is not enough to eradicate residual cells. ERK1/2 activation was also needed for proliferation and awaking dormant cell. Combined therapy of cells undergoing the transition from dormancy to proliferating state with the MEK1/2 inhibitor (AZD6244) and Src inhibitor (AZD0530) potentiated apoptotic death in a large population of the latent cells and postponed development of disseminated disease, none of these was achieved with single-agent therapy [69]. Meanwhile, EGFR signaling via activation of $\mathrm{PI} 3 \mathrm{~K} / \mathrm{AKT} / \mathrm{mTOR}$ and Ras/Raf/ERK axis is another contribution to tumor proliferation [70]. Conversely, TGF $\beta$ signaling represents a therapeutic opportunity to activate a spell of dormancy (Table. 1) [71,72].

An alternative therapeutic approach can be envisioned by preventing cancer cell dormancy. Such that, results of a valuable study unveiled that proliferating and dormant BCCs home in distinct areas within BM niche, with dormant BCCs, mainly occupy perisinusoidal vascular regions that are rich in stromal cell-derived factor 1 (SDF-1) and E-selectin. SDF-1 and E-selectin coordinate opposing functions in BCC, where the SDF-1/CXCR4 axis facilitates adherence of BCCs to the vascular niche, and E-selectin permits BCC entrance into the BM where they remain dormant. Thus, a combined therapy involving CXCR4/E-selectin inhibition will push cells out of their protective niches and aid trapping of the cells in the vasculature, where they could be destroyed with chemotherapy, thus provide an opportunity to control recurrent disease [73].

Cancer stem cells (CSCs) 
DTCs or surviving cells within the tumor during therapy could be stem cells. And, stemness is inherent to dormancy phenotype (Table. 1) [74]. Cumulative evidence suggests that CSCs are indeed metastasis-initiating cells, or metastatic cells acquire CSC-like phenotype upon infiltration into target organs[75]. Tumor cell entrance into and out of dormancy are regulated by contextual cues and intrinsic programs, like those that control the self-renewal ability of mature stem cells [74-76]. Furthermore, a specialized ECM niche nurse reactivation-undergoing metastatic cells, by supporting positive cues, such as Notch and Wnt, and attenuating negative cues, such as BMP [77,78]. Adopting a dormant state, CSCs not only can evade therapeutic killing, the likely reversibility of this situation poses the real threat, which can potentiate deadly relapse or recurrence decades later [79]. Notably, CSCs can adjust the expression of different surface markers which help them to colonize their desired target organs, in particular, the bone[76]. Such that, expression of chemokine receptor CXCR4 (SDF-1 receptor) by BCCs facilitate bone metastasis where osteoblasts express high levels of SDF-1[80]. Moreover, the CXCR4/SDF-1 axis not only derive EMT for bone metastasis, it also promotes cancer cell stemness, plasticity and maintenance of CSC-like properties [80,81].[82]

\section{Epigenetic modification}

As another key regulator of tumor dormancy, epigenetic modifications are involved in the epithelial to mesenchyme transition (EMT) which are associated with CSC phenotype and emergence of drug resistance, tumor dissemination, and high risks of disease relapse. Identifying genes that encode these reversible alterations is an appealing therapeutic plan to combat metastatic disease by inducing differentiation of the mesenchymal cell into an epithelial phenotype [83].

In this respect, epigenetic upregulation of orphan nuclear receptor NR2F1 is detected in DTCs from prostate cancer patients harboring the lifelong dormant disease and in experimental latency models of head and neck squamous cell carcinoma (HNSCC). NR2F1-induced dormancy depends on RAR $\beta$, SOX9 and CDK inhibitors. Also, NR2F1 induces pluripotency gene NANOG, and global chromatin repression, favoring dormancy of DTCs in the bone marrow [84].

Likewise, polycomb-like proteins 1-3 (PCL1-3) are substoichiometric modules of the Polycombrepressive complex 2 (PRC2) that are indispensable for complex association with chromatin. Their functional redundancy is due to their opposing roles in the positive and negative regulation of cellular proliferation. Such that, in quiescent cells, expression of PCL1, a p53 target gene is predominant, while proliferating cells express E2F-regulated genes PCL2 and PCL3. Ectopic expression of any PCL protein employs PRC2 to suppress the INK4A gene; nevertheless, only PCL2 and PCL3 render an INK4A-evolved proliferative benefit. Of note, PCL1 confer a PRC2 function which acts independent of chromatin, possessing anti-proliferating effect and induce cellular dormancy through binding to and stabilizing p53 [85].

Also, in vivo genome-wide short hairpin RNA screening has revealed a novel epigenetic-related mechanism involved in bone metastatic latency of estrogen receptor-positive (ER+) breast cancer. Clinical studies were reported that low levels of mitogen-and stress-activated kinase 1 (MSK1) expression links with an early relapse in ER+ breast cancer patients. In this study, reduced MSK1 impaired the differentiation of breast cancer cells, and increased their bone homing and growth capacities. From a molecular perspective, MSK1 downregulation induces chromatin remodeling and decreases differentiation traits by modulating promoter chromatin status of genes encoding 
GATA3 and FOXA1 transcription factors and accelerates bone colonization by cells in distant micrometastatic sites[86].

\section{Noncoding RNAs (miRNA)}

While the critical role of microRNAs in tumorigenesis is well documented[87], the implication of dormancy miRNAs (Dmirs) are recently illuminated [88]. For example, mesenchymal stem cellderived exosomes comprising different miRNA contents, such as miR-222/223, are shown to induce cycling dormancy and early BC quiescent in BM and give rise to drug resistance. Further, administration of MSC-loaded antagomiR-222/223 sensitized BC cells to carboplatin-based therapy and increased host survival [89]. Also, a recent study showed that metastatic outgrowth of the claudin-low mammary tumor cell line, RJ423 can be avoided by re-expression of the miR200b/200a/429 cluster which promotes epithelial phenotype and induces tumor dormancy [90].

Moreover, a study on experimental models of fast-growing and dormant human osteosarcoma identified three dormancy-associated DmiRs regulating osteosarcoma latency: miR-200c, miR34a, and miR-93. Accordingly, the expression of these microRNAs is lost upon the shift from avascular dormant into angiogenic fast-growing tumor state. Introduction of these miRNAs by dPG-NH2 polyplexes into MG-63 and Saos-2 cells dampened expression levels of their target genes, including hypoxia-inducible factor $1 \alpha$ (HIF1 $\alpha$ ), MET proto-oncogene, and moesin, vital to tumor migration and angiogenesis process. Furthermore, therapy with $\mathrm{dPG}-\mathrm{NH} 2$ containing each of these microRNAs considerably extended the latency state of fast-growing osteosarcomas in mice [91].

Loss of DmiRs expression is also verified in human dormant liposarcoma, breast carcinoma, osteosarcoma and glioblastoma tumors. Transcriptional reprogramming of tumors via overexpression of DmiR-190, 588, or 580 caused reduced expression of pro-angiogenic factors bFGF, TIMP-3, and TGF $\alpha$ while upregulated anti-angiogenic and dormancy stimulating factors Angiomotin and EphA5 [92]. In all dormant tumors analyzed, overexpression of miR-190 was predominant where upregulation of this Dmir encouraged long-term dormancy of otherwise proliferative osteosarcomas and glioblastomas [93].

\section{Stress-induced p38 signaling}

Stress-induced activation of p38 signaling is one of the critical pathways related to tumor dormancy, which regulates a transcriptional network of 46 core genes that includes 16 transcription factors (TFs) [94]. p38 MAPK signaling coordinates the induction of growth arrest and drugresistance in different models of carcinoma dormancy [95]. Imbalances in the activity ratio of ERK to p38 signaling is fundamental to decide the outcome of dormancy vs. tumorigenicity of different experimentally established cancer models (Fig. 2) [96].

Stress-dependent p38 activation induces dormancy by adopting a prosurvival mechanism via enhanced activation of the PERK and up-regulating the endoplasmic reticulum(ER) chaperone $\mathrm{BiP}$, conferring dormant cells resistant to drug toxicity. Moreover, up-regulation of BiP suppresses activation of Bax. Thus, p38 activation via PERK activation and BiP upregulation secures dormant cancer cells from stress insults, such as chemotherapy [97]. Besides, 
p38 activation induces the transcription of the TFs BHLHB3 and p53, while blocking FoxM1 and c-Jun expression. Also, p38-mediated activation of p53 requires down-regulation of c-Jun [94].

ATF6 $\alpha$ as another p38-controlled transcription factor is crucial to the survival of dormancy state. Such that, ATF6 $\alpha$ is crucial for dormant cells adaptation to nutritional stress, chemotherapy, and, most importantly, the in vivo microenvironment. In dormant cancer cells, MKK6 and p38 $\alpha / \beta$ control nuclear translocation and transcriptional activation of ATF6 $\alpha$. Downstream, ATF6 $\alpha$ promotes survival via Akt-independent activation of mTOR signaling and up-regulation of Rheb. Thus, targeting the survival signaling axis ATF6 $\alpha$-Rheb-mTOR in dormant carcinoma cells may help to remove residual disease during dormancy periods [98].

As discussed before, dormant cells and active cells occupy different soils to settle in. That is, nonproliferative DTCs reside in the BM while metastatic growth occurs in other organs such as the lung. Accordingly, BM niche in patients serves as a metastasis 'restrictive soil' by coding dormancy activating clues in DTCs. In this view, in an HNSCC carcinoma model, specific and strong TGF$\beta 2$ signaling in the BM triggers the MAPK $\mathrm{p} 38 \alpha / \beta$, and result in low ERK/p38 signaling ratio. This favor dormancy of malignant DTCs via induction of DEC2/SHARP1 and p27, and CDK4 downregulation. Also, TGF- $\beta 2$-induced latency calls for activation of SMAD1/5, TGF- $\beta$ receptorI (TGF- $\beta$-RI) and TGF- $\beta$-RIII to induce p27. In lungs, a metastasis 'permissive soil' with low TGF$\beta 2$ levels, DTC latency state was transitory and continued by metastatic expansion. Importantly, systemic inhibiting of $\mathrm{p} 38 \alpha / \beta$ or TGF- $\beta$-RI activities awaked dormant DTCs, and fuelled multiorgan metastasis. This work reveals a 'seed and soil' mechanism whereby $\mathrm{p} 38 \alpha / \beta$ regulate TGF- $\beta 2$ and TGF- $\beta$-RIII signaling to determine the fate of DTC dormancy and delineates permissive (lung) and restrictive (BM) microenvironments for HNSCC metastasis [99].

\section{Conclusion and clinical implication}

However, tumor dormancy is commonly regarded as the most threatening face of cancer, leading to the emergence of resistance in a short time and advent of lethal metastatic outbreaks after a long latency period of months to years. Now that we begin to realize dormancy tactics, several therapeutic approaches can be envisioned to outsmart cancer. As illustrated in Fig. 3, these schemes are (i) prolonging dormant state; (ii) eradication of dormant cells; (iii) awakening dormant cells and (iv) avoiding dormancy state. Prolonging dormant state is upon the observation that immunotherapeutic targeting of advanced stage cancers has prolonged the survival of cancer patients, yet its curative efficacy is limited due to tumor immunoediting and escape. On the other hand, human vaccines have been able to eradicate and control many infectious diseases. The success has resulted from the administration of vaccines in prophylactic settings or during latency periods in order to protect an individual during future exposure to the disease rather than curing an established disease. Therefore, administration of immunotherapy at the right time is the key to success. Immunotherapeutic targeting of tumor dormancy could be more promising than targeting of advanced stage disease to achieve a cure for cancer [36]. Besides immunotherapy, identification of Dmirs advocates novel tools to inverse the malignant aggressive phenotype into a microscopic dormant state and may deliver encouraging targets for timely detection or prevention of cancer. Eradication of dormant cells without awakening them is the second tactic in which tricks of dormancy are leveraged against dormant cells. For example, their restrict dependence on survival pathway or altered energy metabolism could be their Achilles heel to interfere with cancer evolution and relapse. Additionally, dormant and resistant cells could be awakened by external stimuli such as growth factors and angiogenic cues, turning them into proliferative yet therapy- 
sensitive tumors. Finally, avoiding dormancy in the first place, by inhibiting pathways leading to the acquisition of dormancy phenotype as discussed in this paper can put an end to all worries about unleashing metastatic cancer.

In conclusion, detection of minimal residual disease in the patients is difficult. Targeting the dormant cells by induction of dormant-to-proliferative switch involves the risk of inducing metastatic progression, while drugs that target DTCs or CSCs might affect normal stem cells. At the end of the day, it is the depth of our knowledge regarding tumor dormancy schemes that will determine the fate of our fight against cancer.

\section{Conflict of interest}

Authors declare none.

\section{Acknowledgments}

We sincerely thank Dr. Siriporn Keeratichamroen and Dr. Martha Glenn for kind scientific editing and fruitful discussions.

Table 1. Molecular cues involved in tumor cell dormancy.

\begin{tabular}{|c|c|c|c|}
\hline Dormancy factor & Mode & Major findings & Ref \\
\hline Angiostatin & $\begin{array}{l}\text { Angiogenic } \\
\text { dormancy }\end{array}$ & $\begin{array}{l}\text { Upregulation of Angiostatin drive long-term dormancy } \\
\text { of primary tumors, inhibit tumor growth, and reduce } \\
\text { cancer metastases. }\end{array}$ & [29] \\
\hline Thrombospondin-1 & $\begin{array}{l}\text { Angiogenic } \\
\text { dormancy }\end{array}$ & $\begin{array}{l}\text { Overexpression of Thrombospondin-1 inhibits } \\
\text { melanoma angiogenesis, lung colonization, and } \\
\text { spontaneous pulmonary metastasis. }\end{array}$ & [30] \\
\hline VEGF/VPF121 & $\begin{array}{l}\text { Angiogenic } \\
\text { dormancy }\end{array}$ & $\begin{array}{l}\text { Overexpression of VEGF/VPF121 result in tumor } \\
\text { growth and escape from dormancy. }\end{array}$ & {$[35]$} \\
\hline $\begin{array}{l}\text { (VEGF(121) } \\
\text { VEGF(165) overexpression }\end{array}$ & $\begin{array}{l}\text { Angiogenic } \\
\text { dormancy }\end{array}$ & \multirow{2}{*}{$\begin{array}{l}\text { The level and VEGF isoforms determine a fate of } \\
\text { aggressive tumor growth vs. nontumorigenic and } \\
\text { dormant tumor. }\end{array}$} & \multirow[t]{2}{*}{ [100] } \\
\hline $\begin{array}{l}\text { VEGF(189) } \\
\text { overexpression }\end{array}$ & $\begin{array}{l}\text { Angiogenic } \\
\text { dormancy }\end{array}$ & & \\
\hline Thrombospondin-1 & $\begin{array}{l}\text { Angiogenic } \\
\text { dormancy }\end{array}$ & \multirow{2}{*}{$\begin{array}{l}\text { Endothelial-derived Thrombospondin-1 induces long- } \\
\text { lasting BCC dormancy. This repressive nod is lost in } \\
\text { sprouting neovasculature where active TGF } \beta 1 \text { and } \\
\text { periostin act as tumor-promoting factors derived from } \\
\text { endothelial tip cells. }\end{array}$} & \multirow[t]{2}{*}{ [33] } \\
\hline TGF $\beta 1$, Periostin & $\begin{array}{l}\text { Angiogenic } \\
\text { dormancy }\end{array}$ & & \\
\hline $\begin{array}{l}\text { Thrombospondin, } \\
\text { Angiomotin, Tropomyosin, } \\
\text { TGF- } \beta 2 \text {, P4HA1, EphA5, } \\
\text { H2BK, IGFBP-5 }\end{array}$ & $\begin{array}{l}\text { Angiogenic } \\
\text { dormancy }\end{array}$ & $\begin{array}{l}\text { Dormant tumors undergo a stable genetic } \\
\text { reprogramming during their switch to the fast-growing } \\
\text { phenotype by downregulation of angiogenesis inhibitors } \\
\text { such as Thrombospondin and decreased the sensitivity }\end{array}$ & [34] \\
\hline
\end{tabular}




\begin{tabular}{|c|c|c|c|}
\hline $\begin{array}{l}\text { EGFR-1, IGF-IR, CD73 } \\
\text { ESM-1, PIK3CB, TIMP-3 }\end{array}$ & $\begin{array}{l}\text { Aangiogenic } \\
\text { dormancy }\end{array}$ & $\begin{array}{l}\text { of angiogenic tumors to Angiostatin along with } \\
\text { upregulation of angiogenesis-related genes. }\end{array}$ & \\
\hline MME1(NM23) & $\begin{array}{l}\text { Angiogenic } \\
\text { dormancy }\end{array}$ & $\begin{array}{l}\text { NM23 inhibits the EGF-induced cell migration. } \\
\text { Increase the expression of metastasis-related genes } \\
\text { TIMP-1, E-Cadherin and } \beta \text {-Catenin, reduce } \\
\text { the expression of VEGR, CD44V6, and MMP- } 2 \text { and } \\
\text { reduce metastasis. }\end{array}$ & [101-103] \\
\hline Kai-1 (CD82) & $\begin{array}{l}\text { Angiogenic } \\
\text { dormancy }\end{array}$ & $\begin{array}{l}\text { Binding of tumor cell surface expressed Kail with } \\
\text { endothelial DARC inhibit tumor cell proliferation, } \\
\text { induce senescence by modulating the expression of } \\
\text { TBX2 and p } 21 \text { and suppress metastasis. }\end{array}$ & [104] \\
\hline BRMS1 & $\begin{array}{l}\text { Angiogenic } \\
\text { dormancy }\end{array}$ & $\begin{array}{l}\text { BRMS1 inhibits angiogenesis through blocking NF/KB } \\
\text { activity. It can also reduce metastatic potential but not } \\
\text { tumorigenicity. }\end{array}$ & [105] \\
\hline HSP27 & $\begin{array}{l}\text { Angiogenic } \\
\text { dormancy }\end{array}$ & $\begin{array}{l}\text { Downregulation of HSP27 associate with reduced } \\
\text { endothelial cell proliferation and decreased secretion of } \\
\text { VEGF-A, VEGF-C, and induction of long-term } \\
\text { dormancy. }\end{array}$ & [106] \\
\hline $\begin{array}{l}\text { CTL response, MHC class } \\
\text { I, NK cells }\end{array}$ & $\begin{array}{l}\text { Immunologic } \\
\text { dormancy }\end{array}$ & $\begin{array}{l}\text { An activate CTL response can maintain immune } \\
\text { equilibrium with metastatic dormant cells. Immune } \\
\text { dormancy arrest cancer cell growth and promotes } \\
\text { angiogenic control. }\end{array}$ & [41] \\
\hline B7-H1 and B7.1 & $\begin{array}{l}\text { Immunologic } \\
\text { dormancy }\end{array}$ & $\begin{array}{l}\text { Dormant tumor cells up-regulate } \mathrm{B} 7 \mathrm{-H} 1 \text { and } \mathrm{B} 7.1 \text { and } \\
\text { resist CTL- mediated lysis. }\end{array}$ & [37] \\
\hline Neutrophils & $\begin{array}{l}\text { Immunologic } \\
\text { dormancy }\end{array}$ & $\begin{array}{l}\text { 14,15-EET trigger neutrophil infiltration in metastatic } \\
\text { lesions by activating STAT3/JNK-hIL-8/mCXCL15 } \\
\text { and mir- } 155 \text { which converts tumor-suppressing function } \\
\text { of neutrophils to tumor-promoting in vivo. } \\
\text { In presence of G-CSF/IL-6, } 14,15 \text {-EET enhance STAT3 } \\
\text { activation in neutrophils to decrease TRAIL expression } \\
\text { and increase MMP-9 expression to induce angiogenesis } \\
\text { during dormant micrometastases growth. } \\
\text { Neutrophil depletion or blocking hIL-8/mCXCL15 } \\
\text { abrogate micrometastases induced by } 14,15 \text {-EET. }\end{array}$ & [107] \\
\hline Zeb1 & $\begin{array}{l}\text { Immunologic } \\
\text { dormancy }\end{array}$ & $\begin{array}{l}\text { Inflammation triggers Zeb1 to promote EMT and give } \\
\text { rise to metastatic outgrowth. }\end{array}$ & [54] \\
\hline TNF $\alpha$, IL- $\beta$ & $\begin{array}{l}\text { Immunologic } \\
\text { dormancy }\end{array}$ & $\begin{array}{l}\text { Addition of bone remodeling cytokines, TNF } \alpha \text { and IL- } \beta \\
\text { to dormant cancer cells induce proliferation and } \\
\text { occurrence of latent bone metastasis. }\end{array}$ & [56] \\
\hline $\begin{array}{l}\text { SOCS1, } \\
\text { IL-3 }\end{array}$ & $\begin{array}{l}\text { Immunologic } \\
\text { dormancy }\end{array}$ & $\begin{array}{l}\text { T-cell inactivation and resistance to apoptosis are } \\
\text { mediated by methylation of SOCS1, deregulation of } \\
\text { JAK/STAT and overproduction of IL-3 by dormant } \\
\text { cells. }\end{array}$ & [47] \\
\hline $\mathrm{IFN}-\gamma$ & $\begin{array}{l}\text { Immunologic } \\
\text { dormancy }\end{array}$ & $\begin{array}{l}\text { IFN- } \gamma \text { signaling triggers differentiated tumor cell } \\
\text { apoptosis via STAT1; however, when IDO1 and AhR } \\
\text { are overexpressed as in DTCs, IFN-gamma induce p27 }\end{array}$ & [44] \\
\hline
\end{tabular}


via IDO1/AhR and inhibits STAT1 signaling, and favors dormancy state.

\begin{tabular}{|c|c|c|}
\hline LPS/EGF & $\begin{array}{l}\text { Immunologic } \\
\text { dormancy }\end{array}$ & $\begin{array}{l}\text { Activated immune/stromal cells stimulate the resident } \\
\text { hepatic cells to derive tumor growth. }\end{array}$ \\
\hline Mitochondrial dysfunction & $\begin{array}{l}\text { Metabolic } \\
\text { dormancy }\end{array}$ & $\begin{array}{l}\text { VLX600 impairs OXPHOS and drives a HIF-1 } \alpha-\text { [58] } \\
\text { dependent switch to glycolysis, which this metabolic } \\
\text { pathway can't meet energy demands of tumor cells, thus } \\
\text { induction of autophagy is unavoidable. Yet, due to lack } \\
\text { of HIF-1 } \alpha \text {-stabilization and glucose inaccessibility in } \\
\text { metabolically stressed environments, shifting to } \\
\text { glycolysis mode will be restricted, consequently, tumor } \\
\text { cells undergo apoptosis. }\end{array}$ \\
\hline LACTB & $\begin{array}{l}\text { Metabolic } \\
\text { dormancy }\end{array}$ & $\begin{array}{l}\text { Mitochondrial tumor suppressor, LACTB potently } \\
\text { inhibits the proliferation of BC cells via altering } \\
\text { mitochondrial lipid metabolism and differentiation of } \\
\text { BC cells by reduction of the levels of mitochondrial } \\
\text { phosphatidylserine decarboxylase, which is involved in } \\
\text { the synthesis of mitochondrial } \\
\text { phosphatidylethanolamine. }\end{array}$ \\
\hline $\begin{array}{l}\text { FA metabolism, ROS, } \\
\text { oxidative DNA damage }\end{array}$ & $\begin{array}{l}\text { Metabolic } \\
\text { dormancy }\end{array}$ & $\begin{array}{l}\text { Residual cells display altered lipid metabolism, elevated } \\
\text { ROS, and increased oxidative DNA damage. Thus, lipid } \\
\text { metabolism and ROS as therapeutic targets for reducing } \\
\text { tumor recurrence in BC patients. }\end{array}$ \\
\hline NR2F1 & $\begin{array}{l}\text { Hypoxic } \\
\text { dormancy }\end{array}$ & 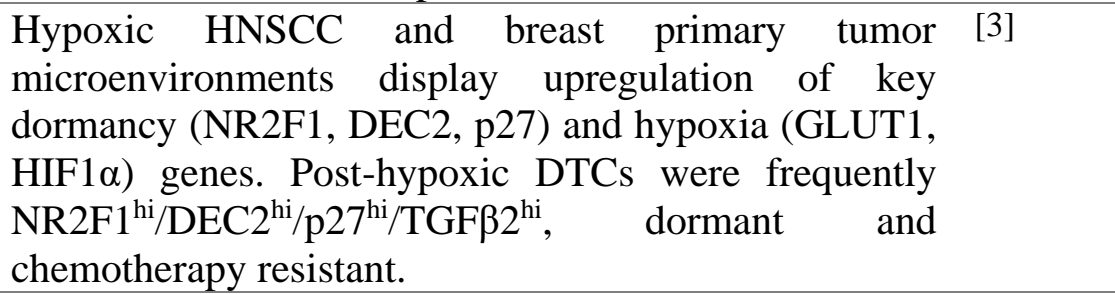 \\
\hline LIFR & $\begin{array}{l}\text { Hypoxic } \\
\text { dormancy }\end{array}$ & $\begin{array}{l}\text { In BC patients with bone metastases, low LIFR levels } \\
\text { negatively correlate with HIF-1 } \alpha \text { activity and disease } \\
\text { outcome. Hypoxia reduces the LIFR:STAT3:SOCS3 } \\
\text { signaling in BC cells. Loss of the LIFR or STAT3 } \\
\text { reactivates dormant BC cells to proliferate and to } \\
\text { downregulate stem cell-related genes and specifically } \\
\text { benefit their bone colonization. }\end{array}$ \\
\hline E6/E7 antigen & $\begin{array}{l}\text { Hypoxic } \\
\text { dormancy }\end{array}$ & $\begin{array}{l}\text { Human papillomavirus-infected cancer cells can enter } \\
\text { into reversible dormancy state, with reducing the } \\
\text { synthesis of viral antigen and enhanced therapeutic } \\
\text { resistance, and uphold tumor recurrence upon } \\
\text { reoxygenation. }\end{array}$ \\
\hline Kiss-1, CRSP3 & $\begin{array}{l}\text { ECM } \\
\text { dormancy }\end{array}$ & $\begin{array}{l}\text { Kiss-1 expression suppresses malignant melanoma } \\
\text { metastasis, inhibits motility, chemotaxis, and invasion, } \\
\text { perhaps by suppressing the expression of MMP-9. } \\
\text { CRSP3 regulate the transcriptional expression of Kiss- } \\
1 \text {. }\end{array}$ \\
\hline
\end{tabular}




\begin{tabular}{|c|c|c|c|}
\hline Type I collagen (Col-I) & $\begin{array}{l}\mathrm{ECM} \\
\text { dormancy }\end{array}$ & $\begin{array}{l}\text { Atypical tetraspanin TM4SF1 as a potent inducer of } \\
\text { metastatic recurrence of BC couples DDR } 1 \text { to PKC } \alpha \text {. } \\
\text { This kinase activates JAK } 2 \text {. Then, JAK2/STAT3 } \\
\text { activates the expression of SOX } 2 \text { and NANOG, } \\
\text { maintain the manifestation of CSC traits, and fuel } \\
\text { metastatic recurrence in the bone, lung, and brain. }\end{array}$ & [113] \\
\hline Fibronectin & $\begin{array}{l}\text { ECM } \\
\text { dormancy }\end{array}$ & $\begin{array}{l}\text { Fibronectin/ } \beta 1 \text { Integrin/MLCK axis induces a transition } \\
\text { from a quiescent to proliferative, metastatic outgrowth. }\end{array}$ & [67] \\
\hline Col-I & $\begin{array}{l}\text { ECM } \\
\text { dormancy }\end{array}$ & $\begin{array}{l}\text { Col-I/ß1 Integrin/SRC/FAK/ERK/MLCK signaling } \\
\text { induce dormant cells to switch to } \\
\text { proliferative metastatic lesions. }\end{array}$ & [68] \\
\hline u-PAR & $\begin{array}{l}\text { ECM } \\
\text { dormancy }\end{array}$ & $\begin{array}{l}\mathrm{u}-\mathrm{PAR}, \text { is an essential molecule } \\
\text { in BM disseminated tumor cells for long-standing } \\
\text { survival during dormancy by regulation of u-PAR of } \\
\alpha 5 \beta 1 \text { integrins, and signal propagation from Fibronectin } \\
\text { through the p38, ERK, and EGF-receptor signaling. }\end{array}$ & $\begin{array}{l}{[66,114-} \\
116]\end{array}$ \\
\hline $\begin{array}{l}\text { FAK, Src, MEK1/2 } \\
(\text { ERK1/2) }\end{array}$ & $\begin{array}{l}\text { ECM } \\
\text { dormancy }\end{array}$ & $\begin{array}{l}\text { Targeting Src prevents the proliferative response of } \\
\text { dormant cells to external stimuli. MEK } 1 / 2 \text { inhibition } \\
\text { suppresses their survival and eliminates tumor relapse. }\end{array}$ & [69] \\
\hline KRAS/C-Myc, IGF1/AKT & $\begin{array}{l}\text { ECM } \\
\text { dormancy }\end{array}$ & $\begin{array}{l}\text { KRAS/C-Myc negative dormant cells represent an } \\
\text { increase in autocrine IGF1/AKT. Inhibition of IGF-1R } \\
\text { reduces residual disease burden and cancer recurrence. }\end{array}$ & [117] \\
\hline TGFB2 & $\begin{array}{l}\text { ECM } \\
\text { dormancy }\end{array}$ & $\begin{array}{l}\text { Cellular adhesion promotes PC cells escape from dorm } \\
\text { ancy and lethal metastasis. The mechanism involves } \\
\text { downregulation of TGFB2, E2F4, and upregulation of } \\
\text { MLCK, CDK6. }\end{array}$ & [72] \\
\hline TGF $\beta 2 /$ GDF 10 & $\begin{array}{l}\text { ECM } \\
\text { dormancy }\end{array}$ & $\begin{array}{l}\text { Osteoblast-secreted proteins induce TGF } 3 \text { RIII- } \\
\text { p38MAPK-pS249/T252RB pathway to mediate } \\
\text { dormancy of metastatic PC in the bone. }\end{array}$ & [118] \\
\hline Axl, Gas6 & $\begin{array}{l}\text { ECM } \\
\text { dormancy }\end{array}$ & $\begin{array}{l}\text { Axl is a tyrosine kinase receptor for growth arrest- } \\
\text { specific } 6 \text { (Gas6). Axl and Gas6 are required for TGF- } \\
\beta 2 \text {-induced dormancy of PC cells in the bone marrow. }\end{array}$ & [71] \\
\hline E-selectin, SDF-1 & $\begin{array}{l}\text { ECM } \\
\text { dormancy }\end{array}$ & $\begin{array}{l}\text { Proliferating and dormant BCCs inhabit different } \\
\text { regions, whereas E-selectin interactions allow BCC } \\
\text { residency in the BM, the SDF-1/CXCR4 binding } \\
\text { anchors BCCs to the metastatic niche. Blocking CXCR } 4 \\
\text { (SDF receptor) and E-selectin eliminates latent } \\
\text { micrometastases residing in supportive bone, excising } \\
\text { occurrence of relapsed disease. }\end{array}$ & [73] \\
\hline MED12 & $\begin{array}{l}\text { ECM } \\
\text { dormancy }\end{array}$ & $\begin{array}{l}\text { The lack of MED12 induces tumor cell dormancy. Re- } \\
\text { expression of MED12 abrogates tumor cell dormancy } \\
\text { by positively controlling EGFR expression. }\end{array}$ & [119] \\
\hline $\mathrm{N}$-cadherin & $\begin{array}{l}\text { CSC } \\
\text { dormancy }\end{array}$ & $\begin{array}{l}\text { N-cadherin upregulation leads to downregulation of E- } \\
\text { cadherin, upregulation of Connexin, EMT, and } \\
\text { dormancy. }\end{array}$ & [120] \\
\hline
\end{tabular}




\begin{tabular}{|c|c|c|c|}
\hline Notch & $\begin{array}{l}\text { CSC } \\
\text { dormancy }\end{array}$ & $\begin{array}{l}\text { Notch remain activated in dormant residual cells and } \\
\text { accelerates tumor recurrence. }\end{array}$ & [121] \\
\hline CD13 & $\begin{array}{l}\text { CSC } \\
\text { dormancy }\end{array}$ & CD13 is a cancer stem cell dormancy marker in HCC. & [122] \\
\hline Coco & $\begin{array}{l}\text { CSC } \\
\text { dormancy }\end{array}$ & $\begin{array}{l}\text { Coco enhances cancer stem cell traits and antagonizes } \\
\text { TGF- } \beta \text { activity. Coco reactivates dormant BC cells in } \\
\text { the lung whereas BMP signaling revives } \\
\text { metastasis dormancy in the lung. }\end{array}$ & [123] \\
\hline BMP7 & $\begin{array}{l}\text { CSC } \\
\text { dormancy }\end{array}$ & $\begin{array}{l}\text { Bone stromal cells-derived BMP7 stimulates } \\
\text { senescence in prostate CSCs by activating BMP7- } \\
\text { BMPR2/p38/p21/NDRG1 axis. }\end{array}$ & [124] \\
\hline SPARC & $\begin{array}{l}\text { CSC } \\
\text { dormancy }\end{array}$ & $\begin{array}{l}\text { SPARC demethylation (activation) significantly } \\
\text { stimulate the expression of BMP7 in bone marrow } \\
\text { stromal cells and is required for BMP7 mediated } \\
\text { stemness and senescence of PC cells. }\end{array}$ & [125] \\
\hline HMGA1 & $\begin{array}{l}\text { CSC } \\
\text { dormancy }\end{array}$ & $\begin{array}{l}\text { HMGA1 reprogram triple negative BC cells to a stem- } \\
\text { like state, driving their metastatic outgrowth. HMGA1 } \\
\text { silencing excise cancer stem/initiator cells and prevents } \\
\text { oncogenesis. }\end{array}$ & [126] \\
\hline TBK1 & $\begin{array}{l}\text { CSC } \\
\text { dormancy }\end{array}$ & $\begin{array}{l}\text { PC cells target the HSC niche in mouse bone marrow } \\
\text { during metastasis. Interaction with niche osteoblasts } \\
\text { activate TBK1 expression and inhibit mTOR in PCa } \\
\text { cells. Silencing TBK1 dampen drug resistance and } \\
\text { formation of PCa stem-like cells. }\end{array}$ & [127] \\
\hline p53, Necdin & $\begin{array}{l}\text { CSC } \\
\text { Dormancy }\end{array}$ & $\begin{array}{l}\text { Necdin-knock out adult HSCs is more proliferative and } \\
\text { less quiescent than wild-type HSCs, indicating that } \\
\text { Necdin resembles p53 function in supporting HSC } \\
\text { dormancy during stable conditions. }\end{array}$ & {$[128,129]$} \\
\hline $\begin{array}{l}\text { Zeb1, G9a, SMAD5, } \\
\text { SMARCD3, KAT5, } \\
\text { DOT1L }\end{array}$ & $\begin{array}{l}\text { Epigenetic } \\
\text { dormancy }\end{array}$ & $\begin{array}{l}\text { These genes control EMT and control dormancy by } \\
\text { reversible activation of stem cell-like properties. }\end{array}$ & [83] \\
\hline PCL1,2,3 & $\begin{array}{l}\text { Epigenetic } \\
\text { dormancy }\end{array}$ & $\begin{array}{l}\text { PCL2 and PCL3 are expressed in proliferative tumor } \\
\text { state, whereas PCL1 mainly expressed in dormant cells. }\end{array}$ & [85] \\
\hline NR2F1 & $\begin{array}{l}\text { Epigenetic } \\
\text { dormancy }\end{array}$ & $\begin{array}{l}\mathrm{NR} 2 \mathrm{~F} 1 \text { is epigenetically upregulated in tumors and } \\
\text { induce dormancy by global chromatin repression. }\end{array}$ & [84] \\
\hline MSK1 & $\begin{array}{l}\text { Epigenetic } \\
\text { dormancy }\end{array}$ & $\begin{array}{l}\text { MSK1 epigenetically controls the differentiation of } \\
\text { cancer cells and its expression promotes metastatic } \\
\text { dormancy. }\end{array}$ & [86] \\
\hline miR-222/223 & $\begin{array}{l}\text { Dmir } \\
\text { dormancy }\end{array}$ & Promotes quiescence and drug resistance. & [89] \\
\hline $\begin{array}{l}\operatorname{miR}-34 \mathrm{a}, \mathrm{miR}-93 \text {, miR- } \\
\text { 200c }\end{array}$ & $\begin{array}{l}\text { Dmir } \\
\text { dormancy }\end{array}$ & $\begin{array}{l}\text { Loss of DmiRNAs happens during the transition from } \\
\text { avascular dormant into angiogenic fast-growing } \\
\text { phenotype. }\end{array}$ & [91] \\
\hline
\end{tabular}




\begin{tabular}{|c|c|c|c|}
\hline $\begin{array}{l}\text { Mir16/19, miR-580, } 588 \text { or } \\
190\end{array}$ & $\begin{array}{l}\text { Dmir } \\
\text { dormancy }\end{array}$ & $\begin{array}{l}\text { Dmirs govern tumor dormancy, especially miR-190 } \\
\text { induce long-lasting dormancy in glioblastomas and } \\
\text { osteosarcomas. }\end{array}$ & {$[92,93]$} \\
\hline miR-100-5p & $\begin{array}{l}\text { Dmir } \\
\text { dormancy }\end{array}$ & $\begin{array}{l}\text { miR-100-5p inhibition induces apoptosis in dormant PC } \\
\text { cells and prevents the emergence of castration-resistant } \\
\text { PC. }\end{array}$ & [130] \\
\hline $\mathrm{miR}-200 \mathrm{~b} / 200 \mathrm{a} / 429$ & $\begin{array}{l}\text { Dmir } \\
\text { dormancy }\end{array}$ & $\begin{array}{l}\text { Expression of these Dmirs induce tumor cell dormancy } \\
\text { and inhibit lung metastasis of BCCs. }\end{array}$ & [90] \\
\hline $\mathrm{miR}-125 \mathrm{~b}$ & $\begin{array}{l}\text { Dmir } \\
\text { dormancy }\end{array}$ & $\begin{array}{l}\text { Its expression favors epithelial phenotype, reduces } \\
\text { WNT-associated stem cell signaling and mesenchymal- } \\
\text { associated genes and thus reduce metastasis of BCCs to } \\
\text { the bone. }\end{array}$ & [131] \\
\hline \multirow[t]{9}{*}{ p38 Signaling } & \multirow{9}{*}{$\begin{array}{l}\text { Stress- } \\
\text { induced } \\
\text { dormancy }\end{array}$} & $\begin{array}{l}\text { p38 Up, ERK down leads to tumor dormancy. } \\
\text { p38 }{ }^{\text {down }} / \text { ERK }^{\text {up }} \text { leads to mitogenesis. }\end{array}$ & {$[95,96]$} \\
\hline & & $\begin{array}{l}\text { p38/BiP/PERK axis promote drug resistance and } \\
\text { survival of quiescent cells. BiP up-regulation averts Bax } \\
\text { activation. }\end{array}$ & [97] \\
\hline & & $\begin{array}{l}\text { p38 induce dormancy by expression of p53 and } \\
\text { BHLHB3 while inhibiting c-Jun and FoxM1. }\end{array}$ & [94] \\
\hline & & $\begin{array}{l}\text { MKK6 and } \mathrm{p} 38 \alpha / \beta \text { induce survival by regulating } \\
\text { nuclear translocation and transcriptional activation of } \\
\text { ATF6 } \alpha \text { in dormant cancer cells. }\end{array}$ & [98] \\
\hline & & $\begin{array}{l}\text { TGF- } \beta 2-M A P K \\
\text { DEC2/SHARP1, p27, } \downarrow \text { CDK } 4 \alpha / \beta \text {, and dormancy of } \\
\text { malignant DTCs. }\end{array}$ & [99] \\
\hline & & $\begin{array}{l}\text { IMERTK, the } \downarrow \text { ratio of P-Erk1/2 to P-p38, } \uparrow \text { p27, } \\
\text { NR2F1, SOX2, and NANOG, } \uparrow \text { histone H3K9me3 and } \\
\text { H3K27me3, G1/G0 arrest and dormancy. }\end{array}$ & [132] \\
\hline & & $\begin{array}{l}\text { MKK4 activates MAPK, p38 and JNK, up-regulate p21 } \\
\text { and induce cancer cell growth arrest. }\end{array}$ & {$[133,134]$} \\
\hline & & MKK6 activates MAPK and p38. & {$[133,134]$} \\
\hline & & MKK7 activates MAPK and JNK. & [135] \\
\hline
\end{tabular}

Abbreviations: N-myc downstream-regulated gene 1 (NDRG1); BMP receptor 2 (BMPR2); indolamine 2,3-dioxygenase 1 (IDO1)-kynurenine (Kyn)-aryl hydrocarbon receptor (AhR) (IDO1/AhR); bone morphogenetic protein 7 (BMP7); N-myc downstream-regulated gene 1 (NDRG1); secreted protein acidic and rich in cysteine (SPARC); high mobility group A1 (HMGA1); polycomb-like proteins 1-3 (PCL1-3); protein kinase-like ER kinase (PERK); urokinase plasminogen activator receptor (UPAR); breast-cancer metastasis suppressor 1 (BRMS1); mammalian target of rapamycin (mTOR); Janus-activated kinase/signal transducers and activators of transcription (JAK/STAT); suppressor of cytokine signaling (SOCS); IL-6 cytokine leukaemia inhibitory factor (LIFR); transforming growth factor $\beta 2$ (TGF- $\beta 2$ ); proline hydroxylase I (P4HA1); Eph receptor A5 (EphA5); histone H2BK; insulin-like growth factor binding protein 5 (IGFBP5); epithelial growth factor receptor (EGFR)-1; insulin-like growth factor type I receptor (IGF-IR); 5'-Ectonucleotidase (CD73); endothelial cell-specific molecule 1 (ESM-1); phosphatidylinositol 3-kinase PI3K 
(PIK3); tissue inhibitor of metalloproteinase-3 (TIMP-3). RNA polymerase II transcriptional mediator subunit 12 (MED12). $\dashv$ denotes suppression, $\uparrow$ denotes upregulation, $\downarrow$ denotes downregulation.

\section{References}

1. Seidi, K.; Neubauer, H.A.; Moriggl, R.; Jahanban-Esfahlan, R.; Javaheri, T. Tumor target amplification: Implications for nano drug delivery systems. Journal of controlled release : official journal of the Controlled Release Society 2018, 275, 142-161, doi:10.1016/j.jconrel.2018.02.020.

2. Jahanban-Esfahlan, R.; Seidi, K.; Banimohamad-Shotorbani, B.; Jahanban-Esfahlan, A.; Yousefi, B. Combination of nanotechnology with vascular targeting agents for effective cancer therapy. Journal of cellular physiology 2017, 233, 2982-2992, doi:10.1002/jcp.26051.

3. Fluegen, G.; Avivar-Valderas, A.; Wang, Y.; Padgen, M.R.; Williams, J.K.; Nobre, A.R.; Calvo, V.; Cheung, J.F.; Bravo-Cordero, J.J.; Entenberg, D., et al. Phenotypic heterogeneity of disseminated tumour cells is preset by primary tumour hypoxic microenvironments. Nature cell biology 2017, 19, 120-132, doi:10.1038/ncb3465.

4. $\quad$ Li, S.; Kennedy, M.; Payne, S.; Kennedy, K.; Seewaldt, V.L.; Pizzo, S.V.; Bachelder, R.E. Model of tumor dormancy/recurrence after short-term chemotherapy. PloS one 2014, 9, e98021, doi:10.1371/journal.pone.0098021.

5. Demicheli, R.; Retsky, M.W.; Hrushesky, W.J.; Baum, M. Tumor dormancy and surgery-driven interruption of dormancy in breast cancer: learning from failures. Nature clinical practice. Oncology 2007, 4, 699-710, doi:10.1038/ncponc0999.

6. $\quad$ Liang, X.; Gu, J.; Li, T.; Zhao, L.; Fu, X.; Zhang, W.; Wang, J.; Shang, Z.; Huang, W.; Zhou, J. PAX5 haploinsufficiency induce cancer cell dormancy in Raji cells. Experimental cell research 2018, 367, 30-36, doi:10.1016/j.yexcr.2018.02.010.

7. Gomis, R.R.; Gawrzak, S. Tumor cell dormancy. Molecular oncology 2016, 11, 62-78, doi:10.1016/j.molonc.2016.09.009.

8. Wu, A.; Liao, D.; Kirilin, V.; Lin, K.C.; Torga, G.; Qu, J.; Liu, L.; Sturm, J.C.; Pienta, K.; Austin, R. Cancer dormancy and criticality from a game theory perspective. Cancer convergence 2018, 2, 1, doi:10.1186/s41236-018-0008-0.

9. Udagawa, T. Tumor dormancy of primary and secondary cancers. APMIS : acta pathologica, microbiologica, et immunologica Scandinavica 2008, 116, 615-628, doi:10.1111/j.16000463.2008.01077.x.

10. Neophytou, C.; Boutsikos, P.; Papageorgis, P. Molecular Mechanisms and Emerging Therapeutic Targets of Triple-Negative Breast Cancer Metastasis. Frontiers in oncology 2018, 8, 31, doi:10.3389/fonc.2018.00031. 
11. Almog, N. Molecular mechanisms underlying tumor dormancy. Cancer letters 2010, 294, 139146, doi:10.1016/j.canlet.2010.03.004.

12. Marx, V. How to pull the blanket off dormant cancer cells. Nature methods 2018, 15, 249-252, doi:10.1038/nmeth.4640.

13. Hedley, B.D.; Chambers, A.F. Tumor dormancy and metastasis. Advances in cancer research 2009, 102, 67-101, doi:10.1016/s0065-230x(09)02003-x.

14. Ya-Fei, D.; Juan-Juan, X. Tumor Cell Dormancy: How It Performs in Drug Resistance and Relapse. Progress Biochem Biophys 2018, 45, 460-470.

15. Aguirre-Ghiso, J.A.; Sosa, M.S. Emerging Topics on Disseminated Cancer Cell Dormancy and the Paradigm of Metastasis. Annual Rev Cancer Biol 2018, 2, 377-393, doi:10.1146/annurevcancerbio-030617-050446.

16. Liang, W.; Ni, Y.; Chen, F. Tumor resistance to vascular disrupting agents: mechanisms, imaging, and solutions. Oncotarget 2016, 7, 15444-15459, doi:10.18632/oncotarget.6999.

17. Tozer, G.M.; Kanthou, C.; Baguley, B.C. Disrupting tumour blood vessels. Nature reviews. Cancer 2005, 5, 423-435, doi:10.1038/nrc1628.

18. Seidi, K.; Jahanban-Esfahlan, R.; Zarghami, N. Tumor rim cells: From resistance to vascular targeting agents to complete tumor ablation. Tumour biology : the journal of the International Society for Oncodevelopmental Biology and Medicine 2017, 39, 1010428317691001, doi:10.1177/1010428317691001.

19. Jahanban-Esfahlan, R.; Seidi, K.; Zarghami, N. Tumor vascular infarction: prospects and challenges. International journal of hematology 2017, 105, 244-256, doi:10.1007/s12185-0162171-3.

20. Jahanban-Esfahlan, R.; Seidi, K.; Monhemi, H.; Adli, A.D.F.; Minofar, B.; Zare, P.; Farajzadeh, D.; Farajnia, S.; Behzadi, R.; Abbasi, M.M., et al. RGD delivery of truncated coagulase to tumor vasculature affords local thrombotic activity to induce infarction of tumors in mice. Sci Rep 2017, 7, 8126, doi:10.1038/s41598-017-05326-9.

21. Daei Farshchi Adli, A.; Jahanban-Esfahlan, R.; Seidi, K.; Samandari-Rad, S.; Zarghami, N. An overview on Vadimezan (DMXAA), the vascular disrupting agent. Chem Biol Drug Des 2017, 10.1111/cbdd.13166, doi: 10.1111/cbdd.13166, doi:10.1111/cbdd.13166.

22. Seidi, K.; Jahanban-Esfahlan, R.; Monhemi, H.; Zare, P.; Minofar, B.; Daei Farshchi Adli, A.; Farajzadeh, D.; Behzadi, R.; Mesgari Abbasi, M.; Neubauer, H.A., et al. NGR (Asn-Gly-Arg)targeted delivery of coagulase to tumor vasculature arrests cancer cell growth. Oncogene 2018, 37, 3967-3980, doi:10.1038/s41388-018-0213-4.

23. Friberg, S.; Nystrom, A. Cancer metastases: early dissemination and late recurrences. Cancer growth and metastasis 2015, 8, 43-49, doi:10.4137/cgm.s31244.

24. Gužvić, M.; Klein, C.A. Cancer dormancy: time to explore its clinical relevance. Breast Cancer Research 2013, 15, 321, doi:10.1186/bcr3590. 
25. Yadav, A.S.; Pandey, P.R.; Butti, R.; Radharani, N.N.V.; Roy, S.; Bhalara, S.R.; Gorain, M.; Kundu, G.C.; Kumar, D. The Biology and Therapeutic Implications of Tumor Dormancy and Reactivation. Frontiers in oncology 2018, 8, 72, doi:10.3389/fonc.2018.00072.

26. Naumov, G.N.; Bender, E.; Zurakowski, D.; Kang, S.Y.; Sampson, D.; Flynn, E.; Watnick, R.S.; Straume, O.; Akslen, L.A.; Folkman, J., et al. A model of human tumor dormancy: an angiogenic switch from the nonangiogenic phenotype. Journal of the National Cancer Institute 2006, 98 , 316-325, doi:10.1093/jnci/djj068.

27. Naumov, G.N.; Folkman, J.; Straume, O. Tumor dormancy due to failure of angiogenesis: role of the microenvironment. Clinical \& experimental metastasis 2009, 26, 51-60, doi:10.1007/s10585008-9176-0.

28. Benzekry, S.; Gandolfi, A.; Hahnfeldt, P. Global dormancy of metastases due to systemic inhibition of angiogenesis. PloS one 2014, 9, e84249, doi:10.1371/journal.pone.0084249.

29. Ambs, S.; Dennis, S.; Fairman, J.; Wright, M.; Papkoff, J. Inhibition of tumor growth correlates with the expression level of a human angiostatin transgene in transfected B16F10 melanoma cells. Cancer research 1999, 59, 5773-5777.

30. Rofstad, E.K.; Graff, B.A. Thrombospondin-1-mediated metastasis suppression by the primary tumor in human melanoma xenografts. The Journal of investigative dermatology 2001, 117, 1042-1049, doi:10.1046/j.0022-202x.2001.01552.x.

31. Almog, N.; Henke, V.; Flores, L.; Hlatky, L.; Kung, A.L.; Wright, R.D.; Berger, R.; Hutchinson, L.; Naumov, G.N.; Bender, E., et al. Prolonged dormancy of human liposarcoma is associated with impaired tumor angiogenesis. FASEB journal : official publication of the Federation of American Societies for Experimental Biology 2006, 20, 947-949, doi:10.1096/fj.05-3946fje.

32. Holmgren, L.; O'Reilly, M.S.; Folkman, J. Dormancy of micrometastases: balanced proliferation and apoptosis in the presence of angiogenesis suppression. Nature medicine 1995, 1, 149-153.

33. Ghajar, C.M.; Peinado, H.; Mori, H.; Matei, I.R.; Evason, K.J.; Brazier, H.; Almeida, D.; Koller, A.; Hajjar, K.A.; Stainier, D.Y., et al. The perivascular niche regulates breast tumour dormancy. Nature cell biology 2013, 15, 807-817, doi:10.1038/ncb2767.

34. Almog, N.; Ma, L.; Raychowdhury, R.; Schwager, C.; Erber, R.; Short, S.; Hlatky, L.; Vajkoczy, P.; Huber, P.E.; Folkman, J., et al. Transcriptional switch of dormant tumors to fast-growing angiogenic phenotype. Cancer research 2009, 69, 836-844, doi:10.1158/0008-5472.can-08-2590.

35. Bayko, L.; Rak, J.; Man, S.; Bicknell, R.; Ferrara, N.; Kerbel, R.S. The dormant in vivo phenotype of early stage primary human melanoma: termination by overexpression of vascular endothelial growth factor. Angiogenesis 1998, 2, 203-217, doi:10.1023/a:1009275307663.

36. Immunotherapy of cancer: targeting cancer during active disease or during dormancy? Immunotherapy 2017, 9, 943-949, doi:10.2217/imt-2017-0044.

37. Quesnel, B. Tumor dormancy and immunoescape. APMIS : acta pathologica, microbiologica, et immunologica Scandinavica 2008, 116, 685-694, doi:10.1111/j.1600-0463.2008.01163.x. 
38. Teng, M.W.; Swann, J.B.; Koebel, C.M.; Schreiber, R.D.; Smyth, M.J. Immune-mediated dormancy: an equilibrium with cancer. Journal of leukocyte biology 2008, 84, 988-993, doi:10.1189/jlb.1107774.

39. Saudemont, A.; Jouy, N.; Hetuin, D.; Quesnel, B. NK cells that are activated by CXCL10 can kill dormant tumor cells that resist CTL-mediated lysis and can express B7-H1 that stimulates T cells. Blood 2005, 105, 2428-2435, doi:10.1182/blood-2004-09-3458.

40. Manjili, M.H.; Butler, S.E. Role of Tregs in cancer dormancy or recurrence. Immunological investigations 2016, 45, 759-766, doi:10.1080/08820139.2016.1194428.

41. Romero, I.; Garrido, F.; Garcia-Lora, A.M. Metastases in immune-mediated dormancy: a new opportunity for targeting cancer. Cancer research 2014, 74, 6750-6757, doi:10.1158/00085472.can-14-2406.

42. Aqbi, H.F.; Wallace, M.; Sappal, S.; Payne, K.K.; Manjili, M.H. IFN-gamma orchestrates tumor elimination, tumor dormancy, tumor escape, and progression. Journal of leukocyte biology $\mathbf{2 0 1 8 ,}$ Doi: 10.1002/jlb.5mir0917-351r, doi:10.1002/jlb.5mir0917-351r.

43. Bakacs, T.; Mehrishi, J.N. Breast and other cancer dormancy as a therapeutic endpoint: speculative recombinant $\mathrm{T}$ cell receptor ligand (RTL) adjuvant therapy worth considering? BMC cancer 2010, 10, 251, doi:10.1186/1471-2407-10-251.

44. Liu, Y.; Liang, X.; Yin, X.; Lv, J.; Tang, K.; Ma, J.; Ji, T.; Zhang, H.; Dong, W.; Jin, X., et al. Blockade of IDO-kynurenine-AhR metabolic circuitry abrogates IFN-gamma-induced immunologic dormancy of tumor-repopulating cells. Nature communications 2017, 8, 15207, doi:10.1038/ncomms15207.

45. Liu, Y.; Lv, J.; Huang, B. Mediating the death of dormant tumor cells. Mol Cell Oncol 2018, 10.1080/23723556.2018.1458013, 1-09, doi:10.1080/23723556.2018.1458013.

46. Saudemont, A.; Quesnel, B. In a model of tumor dormancy, long-term persistent leukemic cells have increased B7-H1 and B7.1 expression and resist CTL-mediated lysis. Blood 2004, 104, 2124-2133, doi:10.1182/blood-2004-01-0064.

47. Saudemont, A.; Hamrouni, A.; Marchetti, P.; Liu, J.; Jouy, N.; Hetuin, D.; Colucci, F.; Quesnel, B. Dormant tumor cells develop cross-resistance to apoptosis induced by CTLs or imatinib mesylate via methylation of suppressor of cytokine signaling 1. Cancer research 2007, 67, 44914498, doi:10.1158/0008-5472.can-06-1627.

48. Rabinovsky, R.; Uhr, J.W.; Vitetta, E.S.; Yefenof, E. Cancer dormancy: lessons from a B cell lymphoma and adenocarcinoma of the prostate. Advances in cancer research 2007, 97, 189-202, doi:10.1016/s0065-230x(06)97008-0.

49. Morecki, S.; Pugatsch, T.; Levi, S.; Moshel, Y.; Slavin, S. Tumor-cell vaccination induces tumor dormancy in a murine model of B-cell leukemia/lymphoma (BCL1). International journal of cancer 1996, 65, 204-208, doi:10.1002/(sici)1097-0215(19960117)65:2<204::aid-ijc13>3.0.co;2d.

50. Manjili, M.H. Tumor dormancy and relapse: from a natural byproduct of evolution to a disease state. Cancer research 2017, 77, 2564-2569, doi:10.1158/0008-5472.can-17-0068. 
51. Cole, S.W. Chronic inflammation and breast cancer recurrence. J Clin Oncol 2009, 27, 34183419, doi:10.1200/JCO.2009.21.9782.

52. Retsky, M.; Demicheli, R.; Hrushesky, W.; Baum, M.; Gukas, I. Surgery triggers outgrowth of latent distant disease in breast cancer: an inconvenient truth? Cancers 2010, 2, 305-337, doi:10.3390/cancers2020305.

53. Krall, J.A.; Reinhardt, F.; Mercury, O.A.; Pattabiraman, D.R.; Brooks, M.W.; Dougan, M.; Lambert, A.W.; Bierie, B.; Ploegh, H.L.; Dougan, S.K., et al. The systemic response to surgery triggers the outgrowth of distant immune-controlled tumors in mouse models of dormancy. Science translational medicine 2018, 10, eaan3464, doi:10.1126/scitranslmed.aan3464.

54. De Cock, J.M.; Shibue, T.; Dongre, A.; Keckesova, Z.; Reinhardt, F.; Weinberg, R.A. Inflammation triggers Zeb1-dependent escape from tumor latency. Cancer research 2016, 76, 6778-6784, doi:10.1158/0008-5472.can-16-0608.

55. Johnson, R.W.; Finger, E.C.; Olcina, M.M.; Vilalta, M.; Aguilera, T.; Miao, Y.; Merkel, A.R.; Johnson, J.R.; Sterling, J.A.; Wu, J.Y., et al. Induction of LIFR confers a dormancy phenotype in breast cancer cells disseminated to the bone marrow. Nature cell biology 2016, 18, 1078-1089, doi:10.1038/ncb3408.

56. Sosnoski, D.M.; Norgard, R.J.; Grove, C.D.; Foster, S.J.; Mastro, A.M. Dormancy and growth of metastatic breast cancer cells in a bone-like microenvironment. Clinical \& experimental metastasis 2015, 32, 335-344, doi:10.1007/s10585-015-9710-9.

57. Jahanban-Esfahlan, R.; de la Guardia, M.; Ahmadi, D.; Yousefi, B. Modulating tumor hypoxia by nanomedicine for effective cancer therapy. Journal of cellular physiology 2017, 233, 2019-2031, doi:10.1002/jcp.25859.

58. Zhang, X.; Fryknas, M.; Hernlund, E.; Fayad, W.; De Milito, A.; Olofsson, M.H.; Gogvadze, V.; Dang, L.; Pahlman, S.; Schughart, L.A., et al. Induction of mitochondrial dysfunction as a strategy for targeting tumour cells in metabolically compromised microenvironments. Nature communications 2014, 5, 3295, doi:10.1038/ncomms4295.

59. Mima, S.; Kakinuma, C.; Higuchi, T.; Saeki, K.; Yamada, T.; Uematsu, R.; Ishino, M.; Kito, N.; Nishikawa, H.; Kuniyoshi, H., et al. FF-10502, an antimetabolite with novel activity on dormant cells, is superior to gemcitabine for targeting pancreatic cancer cells. The Journal of pharmacology and experimental therapeutics 2018, Doi: 10.1124/jpet.118.248740, doi:10.1124/jpet.118.248740.

60. Havas, K.M.; Milchevskaya, V.; Radic, K.; Alladin, A.; Kafkia, E.; Garcia, M.; Stolte, J.; Klaus, B.; Rotmensz, N.; Gibson, T.J., et al. Metabolic shifts in residual breast cancer drive tumor recurrence. The Journal of clinical investigation 2017, 127, 2091-2105, doi:10.1172/jci89914.

61. Torrano, V.; Carracedo, A. Quiescence-like Metabolism to Push Cancer Out of the Race. Cell metabolism 2017, 25, 997-999, doi:10.1016/j.cmet.2017.04.027.

62. Keckesova, Z.; Donaher, J.L.; De Cock, J.; Freinkman, E.; Lingrell, S.; Bachovchin, D.A.; Bierie, B.; Tischler, V.; Noske, A.; Okondo, M.C., et al. LACTB is a tumour suppressor that modulates lipid metabolism and cell state. Nature 2017, 543, 681-686, doi:10.1038/nature21408. 
63. F. Aqbi, H.; Tyutyunyk-Massey, L.; C. Keim, R.; E. Butler, S.; Thekkudan, T.; Joshi, S.; M. Smith, T.; Bandyopadhyay, D.; O. Idowu, M.; D. Bear, H., et al. Autophagy-deficient breast cancer shows early tumor recurrence and escape from dormancy. Oncotarget 2018, 9, 2211322122 .

64. Barkan, D.; Green, J.E.; Chambers, A.F. Extracellular matrix: a gatekeeper in the transition from dormancy to metastatic growth. European journal of cancer (Oxford, England : 1990) 2010, 46, 1181-1188, doi:10.1016/j.ejca.2010.02.027.

65. Keeratichamroen, S.; Lirdprapamongkol, K.; Svasti, J. Mechanism of ECM-induced dormancy and chemoresistance in A549 human lung carcinoma cells. Oncology reports 2018, 39, 17651774, doi:10.3892/or.2018.6258.

66. Allgayer, H.; Aguirre-Ghiso, J.A. The urokinase receptor (u-PAR)--a link between tumor cell dormancy and minimal residual disease in bone marrow? APMIS : acta pathologica, microbiologica, et immunologica Scandinavica 2008, 116, 602-614, doi:10.1111/j.16000463.2008.00997.x.

67. Barkan, D.; Kleinman, H.; Simmons, J.L.; Asmussen, H.; Kamaraju, A.K.; Hoenorhoff, M.J.; Liu, Z.Y.; Costes, S.V.; Cho, E.H.; Lockett, S., et al. Inhibition of metastatic outgrowth from single dormant tumor cells by targeting the cytoskeleton. Cancer research 2008, 68, 6241-6250, doi:10.1158/0008-5472.can-07-6849.

68. Barkan, D.; El Touny, L.H.; Michalowski, A.M.; Smith, J.A.; Chu, I.; Davis, A.S.; Webster, J.D.; Hoover, S.; Simpson, R.M.; Gauldie, J., et al. Metastatic growth from dormant cells induced by a col-I-enriched fibrotic environment. Cancer research 2010, 70, 5706-5716, doi:10.1158/00085472.can-09-2356.

69. El Touny, L.H.; Vieira, A.; Mendoza, A.; Khanna, C.; Hoenerhoff, M.J.; Green, J.E. Combined SFK/MEK inhibition prevents metastatic outgrowth of dormant tumor cells. The Journal of clinical investigation 2014, 124, 156-168, doi:10.1172/jci70259.

70. Chong, C.R.; Jänne, P.A. The quest to overcome resistance to EGFR-targeted therapies in cancer. Nature medicine 2013, 19, 1389, doi:10.1038/nm.3388

https://www.nature.com/articles/nm.3388\#supplementary-information.

71. Yumoto, K.; Eber, M.R.; Wang, J.; Cackowski, F.C.; Decker, A.M.; Lee, E.; Nobre, A.R.; Aguirre-Ghiso, J.A.; Jung, Y.; Taichman, R.S. Axl is required for TGF-beta2-induced dormancy of prostate cancer cells in the bone marrow. Scientific reports 2016, 6, 36520, doi:10.1038/srep36520.

72. Ruppender, N.; Larson, S.; Lakely, B.; Kollath, L.; Brown, L.; Coleman, I.; Coleman, R.; Nguyen, H.; Nelson, P.S.; Corey, E., et al. Cellular adhesion promotes prostate cancer cells escape from dormancy. PloS one 2015, 10, e0130565, doi:10.1371/journal.pone.0130565.

73. Price, T.T.; Burness, M.L.; Sivan, A.; Warner, M.J.; Cheng, R.; Lee, C.H.; Olivere, L.; Comatas, K.; Magnani, J.; Kim Lyerly, H., et al. Dormant breast cancer micrometastases reside in specific bone marrow niches that regulate their transit to and from bone. Science translational medicine 2016, 8, 340ra373, doi:10.1126/scitranslmed.aad4059. 
74. Takeishi, S.; Nakayama, K.I. To wake up cancer stem cells, or to let them sleep, that is the question. Cancer science 2016, 107, 875-881, doi:10.1111/cas.12958.

75. Chen, W.; Dong, J.; Haiech, J.; Kilhoffer, M.C.; Zeniou, M. Cancer stem cell quiescence and plasticity as major challenges in cancer therapy. Stem Cell Int 2016, 2016, 1740936, doi:10.1155/2016/1740936.

76. Plaks, V.; Kong, N.; Werb, Z. The cancer stem cell niche: how essential is the niche in regulating stemness of tumor cells? Cell stem cell 2015, 16, 225-238, doi:10.1016/j.stem.2015.02.015.

77. Giancotti, F.G. Mechanisms governing metastatic dormancy and reactivation. Cell 2013, 155, 750-764, doi:10.1016/j.cell.2013.10.029.

78. Majidinia, M.; Aghazadeh, J.; Jahanban-Esfahlani, R.; Yousefi, B. The roles of Wnt/beta-catenin pathway in tissue development and regenerative medicine. Journal of cellular physiology $\mathbf{2 0 1 7}$ 10.1002/jcp.26265, doi:10.1002/jcp.26265.

79. Ford, A.M.; Mansur, M.B.; Furness, C.L.; van Delft, F.W.; Okamura, J.; Suzuki, T.; Kobayashi, H.; Kaneko, Y.; Greaves, M. Protracted dormancy of pre-leukemic stem cells. Leukemia 2015, 29, 2202-2207, doi:10.1038/leu.2015.132.

80. Roato, I.; Ferracini, R. Cancer Stem Cells, Bone and Tumor Microenvironment: Key Players in Bone Metastases. Cancers 2018, 10, 56, doi:10.3390/cancers10020056.

81. Jung, M.J.; Rho, J.K.; Kim, Y.M.; Jung, J.E.; Jin, Y.B.; Ko, Y.G.; Lee, J.S.; Lee, S.J.; Lee, J.C.; Park, M.J. Upregulation of CXCR4 is functionally crucial for maintenance of stemness in drugresistant non-small cell lung cancer cells. Oncogene 2013, 32, 209-221, doi:10.1038/onc.2012.37.

82. Hu, T.H.; Yao, Y.; Yu, S.; Han, L.L.; Wang, W.J.; Guo, H.; Tian, T.; Ruan, Z.P.; Kang, X.M.; Wang, J., et al. SDF-1/CXCR4 promotes epithelial-mesenchymal transition and progression of colorectal cancer by activation of the Wnt/beta-catenin signaling pathway. Cancer letters 2014, 354, 417-426, doi:10.1016/j.canlet.2014.08.012.

83. Gregoire, J.M.; Fleury, L.; Salazar-Cardozo, C.; Alby, F.; Masson, V.; Arimondo, P.B.; Ausseil, F. Identification of epigenetic factors regulating the mesenchyme to epithelium transition by RNA interference screening in breast cancer cells. BMC cancer 2016, 16, 700, doi:10.1186/s12885-016-2683-5.

84. Sosa, M.S.; Parikh, F.; Maia, A.G.; Estrada, Y.; Bosch, A.; Bragado, P.; Ekpin, E.; George, A.; Zheng, Y.; Lam, H.M., et al. NR2F1 controls tumour cell dormancy via SOX9- and RARbetadriven quiescence programmes. Nature communications 2015, 6, 6170, doi:10.1038/ncomms7170.

85. Brien, G.L.; Healy, E.; Jerman, E.; Conway, E.; Fadda, E.; O'Donovan, D.; Krivtsov, A.V.; Rice, A.M.; Kearney, C.J.; Flaus, A., et al. A chromatin-independent role of Polycomb-like 1 to stabilize p53 and promote cellular quiescence. Genes \& development 2015, 29, 2231-2243, doi:10.1101/gad.267930.115.

86. Gawrzak, S.; Rinaldi, L.; Gregorio, S.; Arenas, E.J.; Salvador, F.; Urosevic, J.; Figueras-Puig, C.; Rojo, F.; Del Barco Barrantes, I.; Cejalvo, J.M., et al. MSK1 regulates luminal cell differentiation 
and metastatic dormancy in ER(+) breast cancer. Nature cell biology 2018, 20, 211-221, doi:10.1038/s41556-017-0021-z.

87. Majidinia, M.; Darband, S.G.; Kaviani, M.; Nabavi, S.M.; Jahanban-Esfahlan, R.; Yousefi, B. Cross-regulation between Notch signaling pathway and miRNA machinery in cancer. DNA Repair 2018, Doi: 10.1016/j.dnarep.2018.04.002, doi:https://doi.org/10.1016/j.dnarep.2018.04.002.

88. Marlow, R.; Honeth, G.; Lombardi, S.; Cariati, M.; Hessey, S.; Pipili, A.; Mariotti, V.; Buchupalli, B.; Foster, K.; Bonnet, D., et al. A novel model of dormancy for bone metastatic breast cancer cells. Cancer research 2013, 73, 6886-6899, doi:10.1158/0008-5472.can-13-0991.

89. Bliss, S.A.; Sinha, G.; Sandiford, O.A.; Williams, L.M.; Engelberth, D.J.; Guiro, K.; Isenalumhe, L.L.; Greco, S.J.; Ayer, S.; Bryan, M., et al. Mesenchymal stem cell-derived exosomes stimulate cycling quiescence and early breast cancer dormancy in bone marrow. Cancer research 2016, 76, 5832-5844, doi:10.1158/0008-5472.can-16-1092.

90. Watson, K.L.; Jones, R.A.; Anthony, B.; Moorehead, R.A. The miR-200b/200a/429 cluster prevents metastasis and induces dormancy in a murine claudin-low mammary tumor cell line. Experimental cell research 2018, Doi: 10.1016/j.yexcr.2018.04.024, doi:10.1016/j.yexcr.2018.04.024.

91. Tiram, G.; Segal, E.; Krivitsky, A.; Shreberk-Hassidim, R.; Ferber, S.; Ofek, P.; Udagawa, T.; Edry, L.; Shomron, N.; Roniger, M., et al. Identification of dormancy-associated MicroRNAs for the design of osteosarcoma-targeted dendritic polyglycerol nanopolyplexes. ACS nano 2016, 10, 2028-2045, doi:10.1021/acsnano.5b06189.

92. Almog, N.; Ma, L.; Schwager, C.; Brinkmann, B.G.; Beheshti, A.; Vajkoczy, P.; Folkman, J.; Hlatky, L.; Abdollahi, A. Consensus micro RNAs governing the switch of dormant tumors to the fast-growing angiogenic phenotype. PloS one 2012, 7, e44001, doi:10.1371/journal.pone.0044001.

93. Almog, N.; Briggs, C.; Beheshti, A.; Ma, L.; Wilkie, K.P.; Rietman, E.; Hlatky, L. Transcriptional changes induced by the tumor dormancy-associated microRNA-190. Transcription 2013, 4, 177-191.

94. Adam, A.P.; George, A.; Schewe, D.; Bragado, P.; Iglesias, B.V.; Ranganathan, A.C.; Kourtidis, A.; Conklin, D.S.; Aguirre-Ghiso, J.A. Computational identification of a p38SAPK-regulated transcription factor network required for tumor cell quiescence. Cancer research 2009, 69, 56645672, doi:10.1158/0008-5472.can-08-3820.

95. Ranganathan, A.C.; Adam, A.P.; Zhang, L.; Aguirre-Ghiso, J.A. Tumor cell dormancy induced by $\mathrm{p} 38 \mathrm{SAPK}$ and ER-stress signaling: an adaptive advantage for metastatic cells? Cancer biology \& therapy 2006, 5, 729-735.

96. Ranganathan, A.C.; Adam, A.P.; Aguirre-Ghiso, J.A. Opposing roles of mitogenic and stress signaling pathways in the induction of cancer dormancy. Cell cycle (Georgetown, Tex.) 2006, 5, 1799-1807, doi:10.4161/cc.5.16.3109.

97. Ranganathan, A.C.; Zhang, L.; Adam, A.P.; Aguirre-Ghiso, J.A. Functional coupling of p38induced up-regulation of $\mathrm{BiP}$ and activation of RNA-dependent protein kinase-like endoplasmic 
reticulum kinase to drug resistance of dormant carcinoma cells. Cancer research 2006, 66, 17021711, doi:10.1158/0008-5472.can-05-3092.

98. Schewe, D.M.; Aguirre-Ghiso, J.A. ATF6alpha-Rheb-mTOR signaling promotes survival of dormant tumor cells in vivo. Proceedings of the National Academy of Sciences of the United States of America 2008, 105, 10519-10524, doi:10.1073/pnas.0800939105.

99. Bragado, P.; Estrada, Y.; Parikh, F.; Krause, S.; Capobianco, C.; Farina, H.G.; Schewe, D.M.; Aguirre-Ghiso, J.A. TGF-beta2 dictates disseminated tumour cell fate in target organs through TGF-beta-RIII and p38alpha/beta signalling. Nature cell biology 2013, 15, 1351-1361, doi:10.1038/ncb2861.

100. Yu, J.L.; Rak, J.W.; Klement, G.; Kerbel, R.S. Vascular endothelial growth factor isoform expression as a determinant of blood vessel patterning in human melanoma xenografts. Cancer research 2002, 62, 1838-1846.

101. Russell, R.L.; Pedersen, A.N.; Kantor, J.; Geisinger, K.; Long, R.; Zbieranski, N.; Townsend, A.; Shelton, B.; Brunner, N.; Kute, T.E. Relationship of nm23 to proteolytic factors, proliferation and motility in breast cancer tissues and cell lines. British journal of cancer 1998, 78, 710-717.

102. Suzuki, E.; Ota, T.; Tsukuda, K.; Okita, A.; Matsuoka, K.; Murakami, M.; Doihara, H.; Shimizu, N. nm23-H1 reduces in vitro cell migration and the liver metastatic potential of colon cancer cells by regulating myosin light chain phosphorylation. International journal of cancer 2004, 108, 207-211, doi:10.1002/ijc.11546.

103. Che, G.; Chen, J.; Liu, L.; Wang, Y.; Li, L.; Qin, Y.; Zhou, Q. Transfection of nm23-H1 increased expression of beta-Catenin, E-Cadherin and TIMP-1 and decreased the expression of MMP-2, CD44v6 and VEGF and inhibited the metastatic potential of human non-small cell lung cancer cell line L9981. Neoplasma 2006, 53, 530-537.

104. Bandyopadhyay, S.; Zhan, R.; Chaudhuri, A.; Watabe, M.; Pai, S.K.; Hirota, S.; Hosobe, S.; Tsukada, T.; Miura, K.; Takano, Y., et al. Interaction of KAI1 on tumor cells with DARC on vascular endothelium leads to metastasis suppression. Nature medicine 2006, 12, 933-938, doi:10.1038/nm1444.

105. Seraj, M.J.; Samant, R.S.; Verderame, M.F.; Welch, D.R. Functional evidence for a novel human breast carcinoma metastasis suppressor, BRMS1, encoded at chromosome 11q13. Cancer research 2000, 60, 2764-2769.

106. Straume, O.; Shimamura, T.; Lampa, M.J.; Carretero, J.; Oyan, A.M.; Jia, D.; Borgman, C.L.; Soucheray, M.; Downing, S.R.; Short, S.M., et al. Suppression of heat shock protein 27 induces long-term dormancy in human breast cancer. Proceedings of the National Academy of Sciences of the United States of America 2012, 109, 8699-8704, doi:10.1073/pnas.1017909109.

107. Luo, J.; Feng, X.X.; Luo, C.; Wang, Y.; Li, D.; Shu, Y.; Wang, S.S.; Qin, J.; Li, Y.C.; Zou, J.M., et al. 14,15-EET induces the infiltration and tumor-promoting function of neutrophils to trigger the growth of minimal dormant metastases. Oncotarget 2016, 7, 43324-43336, doi:10.18632/oncotarget.9709.

108. Clark, A.M.; Kumar, M.P.; Wheeler, S.E.; Young, C.L.; Venkataramanan, R.; Stolz, D.B.; Griffith, L.G.; Lauffenburger, D.A.; Wells, A. A Model of Dormant-Emergent Metastatic Breast 
Cancer Progression Enabling Exploration of Biomarker Signatures. Molecular \& cellular proteomics : MCP 2018, 17, 619-630, doi:10.1074/mcp.RA117.000370.

109. Hoppe-Seyler, K.; Bossler, F.; Lohrey, C.; Bulkescher, J.; Rosl, F.; Jansen, L.; Mayer, A.; Vaupel, P.; Durst, M.; Hoppe-Seyler, F. Induction of dormancy in hypoxic human papillomavirus-positive cancer cells. Proceedings of the National Academy of Sciences of the United States of America 2017, 114, E990-e998, doi:10.1073/pnas.1615758114.

110. Szalmas, A. Commentary: Induction of Dormancy in Hypoxic Human Papillomavirus-Positive Cancer Cells. Frontiers in oncology 2018, 8, 77, doi:10.3389/fonc.2018.00077.

111. Lee, J.H.; Miele, M.E.; Hicks, D.J.; Phillips, K.K.; Trent, J.M.; Weissman, B.E.; Welch, D.R. KiSS-1, a novel human malignant melanoma metastasis-suppressor gene. Journal of the National Cancer Institute 1996, 88, 1731-1737.

112. Goldberg, S.F.; Miele, M.E.; Hatta, N.; Takata, M.; Paquette-Straub, C.; Freedman, L.P.; Welch, D.R. Melanoma metastasis suppression by chromosome 6: evidence for a pathway regulated by CRSP3 and TXNIP. Cancer research 2003, 63, 432-440.

113. Gao, H.; Chakraborty, G.; Zhang, Z.; Akalay, I.; Gadiya, M.; Gao, Y.; Sinha, S.; Hu, J.; Jiang, C.; Akram, M., et al. Multi-organ Site Metastatic Reactivation Mediated by Non-canonical Discoidin Domain Receptor 1 Signaling. Cell 2016, 166, 47-62, doi:10.1016/j.cell.2016.06.009.

114. Aguirre-Ghiso, J.A.; Estrada, Y.; Liu, D.; Ossowski, L. ERK(MAPK) activity as a determinant of tumor growth and dormancy; regulation by p38(SAPK). Cancer research 2003, 63, 1684-1695.

115. Aguirre-Ghiso, J.A.; Liu, D.; Mignatti, A.; Kovalski, K.; Ossowski, L. Urokinase receptor and fibronectin regulate the ERK(MAPK) to p38(MAPK) activity ratios that determine carcinoma cell proliferation or dormancy in vivo. Molecular biology of the cell 2001, 12, 863-879.

116. Ghiso, J.A.A.; Kovalski, K.; Ossowski, L. Tumor dormancy induced by downregulation of urokinase receptor in human carcinoma involves integrin and MAPK signaling. J Cell Biol 1999, 147, 89-104.

117. Rajbhandari, N.; Lin, W.C.; Wehde, B.L.; Triplett, A.A.; Wagner, K.U. Autocrine IGF1 signaling mediates pancreatic tumor cell dormancy in the absence of oncogenic drivers. Cell reports 2017, 18, 2243-2255, doi:10.1016/j.celrep.2017.02.013.

118. Yu-Lee, L.Y.; Yu, G.; Lee, Y.C.; Lin, S.C.; Pan, J.; Pan, T.; Yu, K.J.; Liu, B.; Creighton, C.J.; Rodriguez-Canales, J., et al. Osteoblast-secreted factors mediate dormancy of metastatic prostate cancer in the bone via activation of the TGFbetaRIII-p38MAPK-pS249/T252RB pathway. Cancer research 2018, Doi: 10.1158/0008-5472.can-17-1051, doi:10.1158/0008-5472.can-171051.

119. Luo, X.L.; Deng, C.; Su, X.D.; Wang, F.; Chen, Z.; Wu, X.P.; Liang, S.B.; Liu, J.; Fu, L. Loss of MED12 induces tumor dormancy in human epithelial ovarian cancer via downregulation of EGFR. Cancer research 2018, Doi: 10.1158/0008-5472.can-18-0134, doi:10.1158/00085472.can-18-0134.

120. Sinha, G.; Rameshwar, P. N-cadherin in cancer dormancy. Cell Death Ther 2015, 1, 23-27. 
121. Abravanel, D.L.; Belka, G.K.; Pan, T.C.; Pant, D.K.; Collins, M.A.; Sterner, C.J.; Chodosh, L.A. Notch promotes recurrence of dormant tumor cells following HER2/neu-targeted therapy. The Journal of clinical investigation 2015, 125, 2484-2496, doi:10.1172/jci74883.

122. Marusawa, H.; Chiba, T. A marker for dormant cancer stem cells in human hepatocellular carcinoma. Gastroenterology 2011, 140, 1353-1355; discussion 1355, doi:10.1053/j.gastro.2011.02.039.

123. Gao, H.; Chakraborty, G.; Lee-Lim, A.P.; Mo, Q.; Decker, M.; Vonica, A.; Shen, R.; Brogi, E.; Brivanlou, A.H.; Giancotti, F.G. The BMP Inhibitor Coco Reactivates Breast Cancer Cells at Lung Metastatic sites. Cell 2012, 150, 764-779, doi:10.1016/j.cell.2012.06.035.

124. Kobayashi, A.; Okuda, H.; Xing, F.; Pandey, P.R.; Watabe, M.; Hirota, S.; Pai, S.K.; Liu, W.; Fukuda, K.; Chambers, C., et al. Bone morphogenetic protein 7 in dormancy and metastasis of prostate cancer stem-like cells in bone. The Journal of experimental medicine 2011, 208, 26412655, doi:10.1084/jem.20110840.

125. Sharma, S.; Xing, F.; Liu, Y.; Wu, K.; Said, N.; Pochampally, R.; Shiozawa, Y.; Lin, H.K.; Balaji, K.C.; Watabe, K. Secreted Protein Acidic and Rich in Cysteine (SPARC) Mediates Metastatic Dormancy of Prostate Cancer in Bone. The Journal of biological chemistry 2016, 291, 19351-19363, doi:10.1074/jbc.M116.737379.

126. Shah, S.N.; Cope, L.; Poh, W.; Belton, A.; Roy, S.; Talbot, C.C., Jr.; Sukumar, S.; Huso, D.L.; Resar, L.M. HMGA1: a master regulator of tumor progression in triple-negative breast cancer cells. PloS one 2013, 8, e63419, doi:10.1371/journal.pone.0063419.

127. Kim, J.K.; Jung, Y.; Wang, J.; Joseph, J.; Mishra, A.; Hill, E.E.; Krebsbach, P.H.; Pienta, K.J.; Shiozawa, Y.; Taichman, R.S. TBK1 regulates prostate cancer dormancy through mTOR inhibition. Neoplasia (New York, N.Y.) 2013, 15, 1064-1074.

128. Asai, T.; Liu, Y.; Di Giandomenico, S.; Bae, N.; Ndiaye-Lobry, D.; Deblasio, A.; Menendez, S.; Antipin, Y.; Reva, B.; Wevrick, R., et al. Necdin, a p53 target gene, regulates the quiescence and response to genotoxic stress of hematopoietic stem/progenitor cells. Blood 2012, 120, 1601-1612, doi:10.1182/blood-2011-11-393983.

129. Liu, Y.; Elf, S.E.; Miyata, Y.; Sashida, G.; Liu, Y.; Huang, G.; Di Giandomenico, S.; Lee, J.M.; Deblasio, A.; Menendez, S., et al. p53 regulates hematopoietic stem cell quiescence. Cell stem cell 2009, 4, 37-48, doi:10.1016/j.stem.2008.11.006.

130. Nabavi, N.; Saidy, N.R.N.; Venalainen, E.; Haegert, A.; Parolia, A.; Xue, H.; Wang, Y.; Wu, R.; Dong, X.; Collins, C., et al. miR-100-5p inhibition induces apoptosis in dormant prostate cancer cells and prevents the emergence of castration-resistant prostate cancer. Scientific reports 2017, 7, 4079, doi:10.1038/s41598-017-03731-8.

131. Maroni, P.; Bendinelli, P.; Matteucci, E.; Desiderio, M.A. The therapeutic effect of miR-125b is enhanced by the prostaglandin endoperoxide synthase $2 /$ cyclooxygenase 2 blockade and hampers ETS1 in the context of the microenvironment of bone metastasis. Cell death \& disease 2018, 9 , 472, doi:10.1038/s41419-018-0499-8.

132. Cackowski, F.C.; Eber, M.R.; Rhee, J.; Decker, A.M.; Yumoto, K.; Berry, J.E.; Lee, E.; Shiozawa, Y.; Jung, Y.; Aguirre-Ghiso, J.A., et al. Mer Tyrosine Kinase Regulates Disseminated 
Prostate Cancer Cellular Dormancy. Journal of cellular biochemistry 2017, 118, 891-902, doi:10.1002/jcb.25768.

133. Lotan, T.; Hickson, J.; Souris, J.; Huo, D.; Taylor, J.; Li, T.; Otto, K.; Yamada, S.D.; Macleod, K.; Rinker-Schaeffer, C.W. c-Jun NH2-terminal kinase activating kinase 1/mitogen-activated protein kinase kinase 4-mediated inhibition of SKOV3ip.1 ovarian cancer metastasis involves growth arrest and p21 up-regulation. Cancer research 2008, 68, 2166-2175, doi:10.1158/00085472.can-07-1568.

134. Paez, D.; Labonte, M.J.; Bohanes, P.; Zhang, W.; Benhanim, L.; Ning, Y.; Wakatsuki, T.; Loupakis, F.; Lenz, H.J. Cancer dormancy: a model of early dissemination and late cancer recurrence. Clinical cancer research : an official journal of the American Association for Cancer Research 2012, 18, 645-653, doi:10.1158/1078-0432.ccr-11-2186.

135. Vander Griend, D.J.; Kocherginsky, M.; Hickson, J.A.; Stadler, W.M.; Lin, A.; Rinker-Schaeffer, C.W. Suppression of metastatic colonization by the context-dependent activation of the c-Jun NH2-terminal kinase kinases JNKK1/MKK4 and MKK7. Cancer research 2005, 65, 1098410991, doi:10.1158/0008-5472.can-05-2382. 


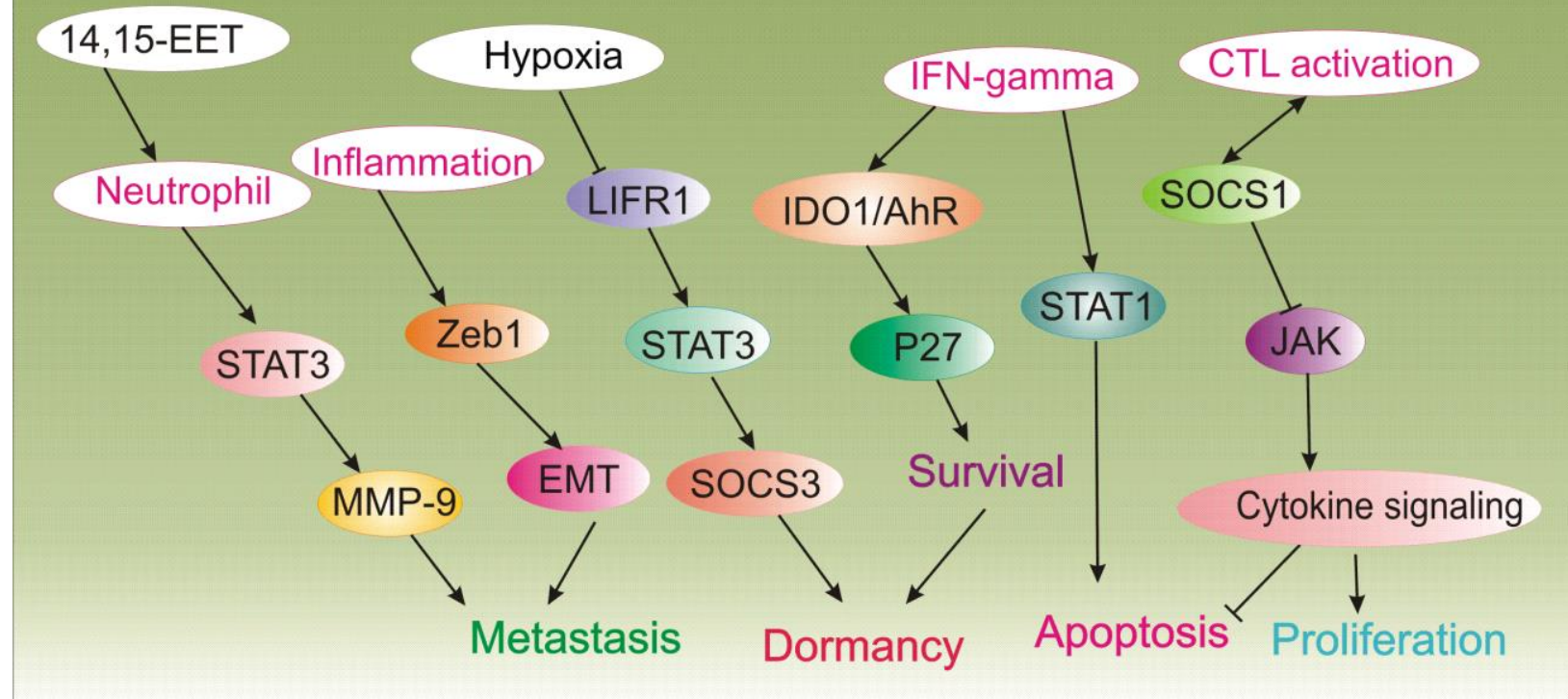

Fig. 1. The implication of immune system in tumor cell dormancy. 


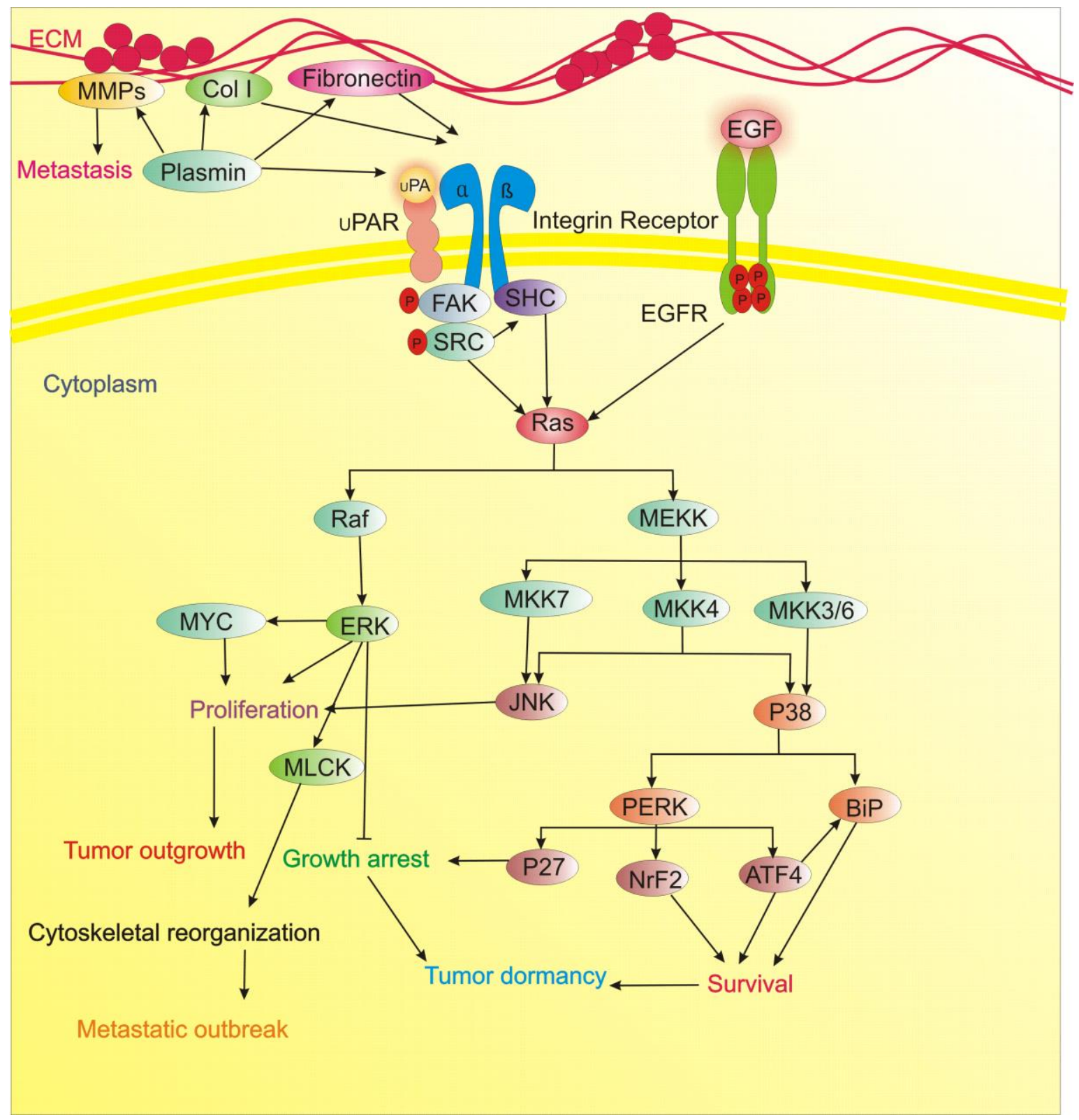

Fig. 2. The implication of ECM and $\mathrm{p} 38$ signaling in tumor dormancy. 


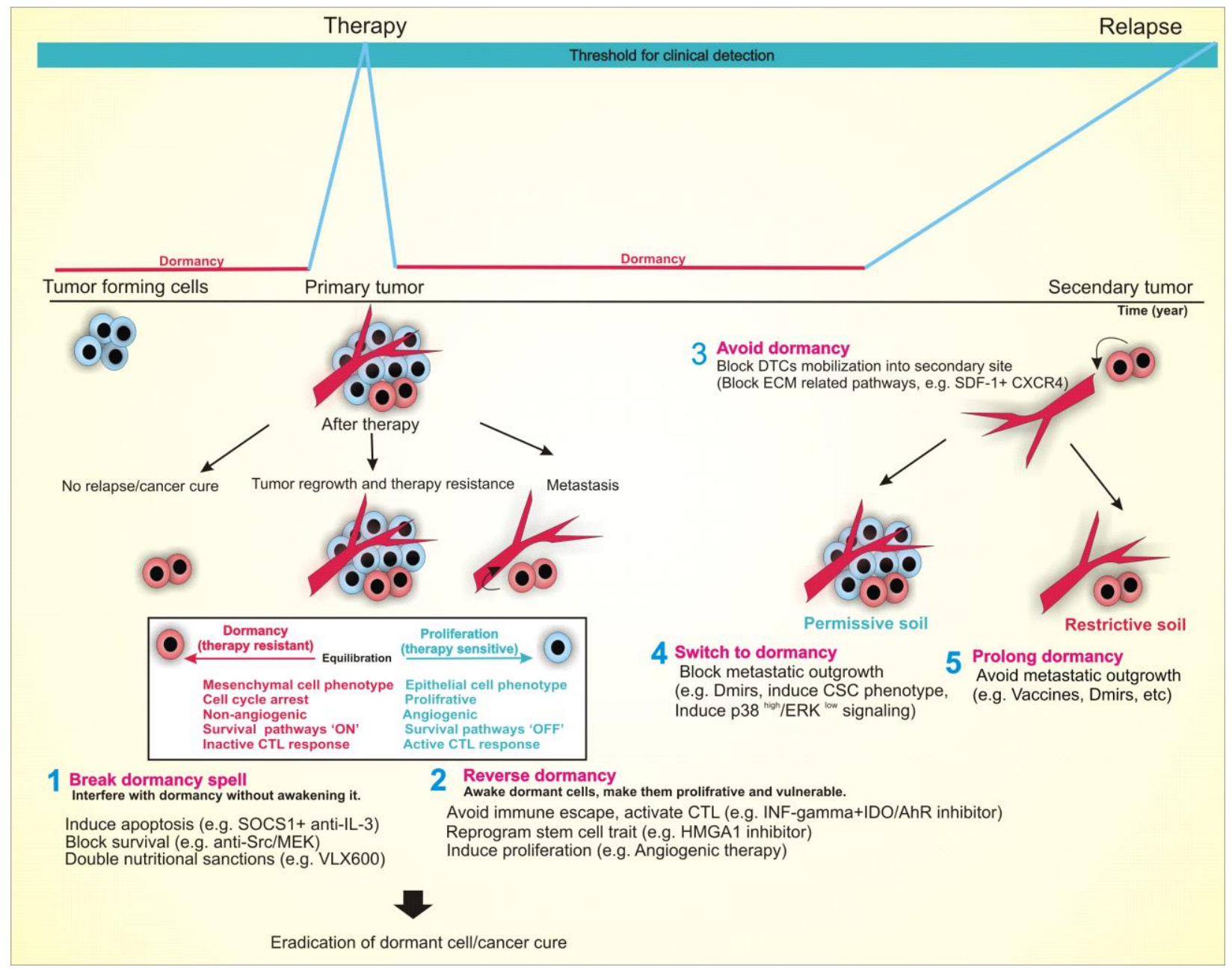

Fig. 3. Tumor dormancy as a therapeutic opportunity to fight cancer back. 